\title{
53. LATEST CRETACEOUS TO CENOZOIC CLIMATE AND OCEANOGRAPHIC DEVELOPMENTS IN THE WEDDELL SEA, ANTARCTICA: AN OCEAN-DRILLING PERSPECTIVE 1
}

\author{
James P. Kennett ${ }^{2}$ and Peter F. Barker ${ }^{3}$
}

\begin{abstract}
This is a summary of principal findings made by ODP Leg 113 investigators concerning the latest Cretaceous-Cenozoic climatic, cryospheric, and oceanographic history, and biogeographic developments of the Weddell Sea region, Antarctica. During Leg 113, 22 holes were drilled at 9 sites that sampled 4 contrasting environments: open-ocean pelagic sedimentation on Maud Rise (Sites 689 and 690), hemipelagic and terrigenous sediments on the East Antarctic Continental Margin (Sites 691-693), a turbiditic sequence in the deep Weddell Basin (Site 694), and hemipelagic and biogenic sediments on the South Orkney microcontinent (Sites 695-697).

A wide range of sedimentologic, biotic, and isotopic evidence obtained in Leg 113 material indicates that sequential cooling and cryospheric development of Antarctica and the surrounding oceans during the Cenozoic profoundly affected the ocean/atmosphere circulation, sediments, and biota. Important cooling steps occurred during the latest Cretaceous, the middle Eocene, near the Eocene/Oligocene boundary, in the middle Oligocene, the middle Miocene, the early late Miocene, the latest Miocene, and the late Pliocene. Distinct but temporary warming trends occurred during the late Paleocene and the latest Oligocene to early Miocene. Principal findings include the following:
\end{abstract}

1. Late Cretaceous climatic conditions were temperate to cool subtropical in the Weddell Sea sector of the Antarctic with no evidence of cryospheric development.

2. A significant warming episode began about $500 \mathrm{k}$.y. prior to the mass extinction event at the Cretaceous/Tertiary boundary. This was followed by a marked cooling and a positive carbon isotopic shift that immediately preceded $(\sim 200$ k.y.) the boundary.

3. The Paleocene section at Site 690 contains fine-grained sediments, possibly of eolian origin and derived from East Antarctica; the presence of this material suggests that climate was warm, semiarid, and continental at that time.

4. A warming trend occurred during the late Paleocene, leading to the climax of Cenozoic warmth during the early to early middle Eocene ( $\sim 58$ to $45 \mathrm{Ma}$ ). Conspicuous paleoenvironmental and biotic changes mark the Paleocene/Eocene boundary, including a brief climatic spike when surface water temperatures in the Weddell Sea increased to as much as $20^{\circ} \mathrm{C}$.

5. The early Paleogene high-latitude ocean seems to have been marked by high seasonal variation in sea-surface temperatures and a well-developed seasonal thermocline. With cooling of the high latitudes during the middle to late Paleogene, this seasonal variation decreased, as did vertical water mass stratification.

6. Antarctica may not have been the primary source of deep waters during at least part of the Eocene. Oxygen isotopic evidence indicates the presence of warm saline deep water in the Weddell Sea at times during the Eocene. The warmer deep waters are inferred to have been produced at lower latitudes.

7. At the beginning of the Oligocene, cold deep water began to form in the Antarctic and upwardly displaced warmer waters that were probably still being formed at lower latitudes.

8. On Maud Rise, a siliceous biogenic facies began to replace a carbonate facies with initial siliceous sedimentation in the latest Eocene-earliest Oligocene, leading to an almost completely siliceous biofacies by the late Miocene ( $\sim 9$ Ma). Near the beginning of the Neogene, there was a pronounced increase in the siliceous relative to the calcareous biofacies on Maud Rise. This coincides with the development of the siliceous biofacies observed in other sectors of Antarctica and probably reflects the development of a strong modern upwelling regime in the Antarctic that was also typical of the late Neogene.

9. Diverse calcareous planktonic assemblages reflect the relative warmth of surficial waters off Antarctica from the Late Cretaceous through the Eocene. Near the northern Antarctic Peninsula, a diverse middle to late Eocene palynoflora indicates the presence of forest dominated by Nothofagus with an undergrowth containing ferns. During the late Eocene, diversity began to decrease in planktonic assemblages as the Southern Ocean cooled; diversity sharply dropped near the Eocene/Oligocene boundary. The ultimate replacement of calcareous by siliceous assemblages by the late Miocene was in response to continued cooling and upwelling conditions throughout the circum-Antarctic.

10. The Leg 113 evidence suggests that cryospheric development began early in the Oligocene ( $36 \mathrm{Ma})$ at least in this sector of the Antarctic. Oligocene sequences drilled during Leg 113 on the Antarctic continental margin (Sites 692, 693, and 696) do not provide the required resolution to decipher details about cryospheric development during the Oligocene, especially with respect to determining if an ice-sheet accumulated on the continent at this time. We found no evidence for major ice accumulation during the Oligocene. The oxygen isotopic record from Site 689 contains evidence of some ice growth on East Antarctica (isotopic values $>2.5 \%$ ) during the early to early late Oligocene. This is further supported by the presence of probable ice-rafted detritus at Site 693 during the late early Oligocene, the earliest detected during Leg 113. Comparison with evidence from other sectors suggests possible diachronism of ice accumulation around the margin of East Antarctica.

\footnotetext{
${ }^{1}$ Barker, P. F., Kennett, J. P., et al., 1990. Proc. ODP, Sci. Results, 113: College Station, TX (Ocean Drilling Program).

2 Marine Sciences Institute and Department of Geological Sciences, University of California at Santa Barbara, Santa Barbara, CA 93106.

${ }^{3}$ British Antarctic Survey, Madingley Road, Cambridge CB3 OET, United Kingdom.
} 
11. Biogeographic similarity during the Oligocene between Maud Rise and the Falkland Plateau areas indicates an absence of the Antarctic Circumpolar Current and the Polar Front. Instead, major modifications of surface and intermediate water masses during the Oligocene took place within the southern Weddell Sea rather than to the north.

12. Leg 113 data suggest that no ice-sheets of continental proportions had developed prior to the middle Miocene. The glacial development of Antarctica intensified during the Neogene, leading to the formation of a possibly permanent ice-sheet on West Antarctica during the latest Miocene-earliest Pliocene.

13. Comparison of the sedimentary sequences in the various Weddell Sea sectors indicates diachronism of ice-sheet formation and climate change. The East Antarctic ice-sheet formed first, followed by the West Antarctic ice-sheet during the late Miocene $(\sim 8 \mathrm{Ma})$.

14. Combined sedimentologic, biotic, and isotopic evidence from Leg 113 sequences indicates that the middle to late Paleogene climate change was dominantly cooling while latest Paleogene-Neogene change was dominantly cryospheric development (ice accumulation).

15. A rapid influx of terrigenous turbidites to the Weddell Abyssal Plain (Site 694) during the latest Miocene and perhaps earliest Pliocene is considered to mark the growth of the West Antarctic ice-sheet. The virtual cessation of turbidite deposition at Site 694, in the earliest Pliocene ( $~ 4.8 \mathrm{Ma})$, suggests that the West Antarctic ice-sheet may have become a permanent and stable feature at that time.

16. During the late Pliocene $(\sim 2.4 \mathrm{Ma})$, a reduction in sedimentation rates and diatom abundances and a deterioration in microfossil preservation at most sites represent yet another step in ice growth and an expansion of sea-ice and was related to further global climatic cooling at that time.

17. The Quaternary includes a remarkable layer (up to $2.5 \mathrm{~m}$ thick) of foraminiferal ooze or a calcareous foraminiferal-rich zone in the shallower sites $(<\sim 3000 \mathrm{~m})$ drilled in the Weddell Sea. Associated planktonic microfossils indicate that this layer was deposited during a brief climatic amelioration associated with changes in water mass chemistry and a depression of the CCD.

18. The numerous discoveries of Leg 113 have reaffirmed the necessity for further Antarctic drilling to improve the understanding of global environmental evolution.

\section{INTRODUCTION}

The Antarctic region is a rich and vital repository of paleoenvironmental information important for understanding global climatic evolution and its causes, the development of the Antarctic cryosphere, and sea-level history. Regional studies are also necessary for understanding the history of formation of deep and intermediate waters that have supplied the world ocean, oceanic upwelling and biological productivity, and the evolution of the marine biota.

The climatic evolution of the Earth during the Cenozoic largely reflects a trend toward lower temperatures and cryospheric development of the polar regions, initially in Antarctica and later in the Northern Hemisphere. This evolution resulted in an increase in the global meridional thermal gradient at the surface of the oceans (Savin et al., 1975; Shackleton and Kennett, 1975; Kennett, 1977; Loutit et al., 1983). An understanding of the climatic, paleoceanographic, and cryospheric evolution of Antarctica is crucial to a broader understanding of global long-term climatic and oceanographic change (Hayes et al., 1975; Kennett, Houtz, et al., 1975; Kennett, 1977) and assists in our understanding of modern oceanographic and climatic processes. Through geologic time, major interactions between the hydrosphere, cryosphere, atmosphere, and biosphere have affected the entire global system through climatic feedbacks, biogeochemical cycles, deep ocean circulation, and sea-level changes. The Antarctic region may be highly sensitive to externally imposed change and, conversely, has played a major role in affecting climatic change elsewhere on earth during the Cenozoic. Processes linking the low-latitude regions with Antarctica as a heat sink play a major role in driving global circulation.

The climatic development of the Southern Ocean resulted, in part, from the rearrangement of the Southern Hemisphere land masses. Antarctica became increasingly isolated as fragments of Gondwanaland dispersed northward and circumpolar circulation developed, allowing unrestricted latitudinal flow. Development of the Antarctic Circumpolar Current during the middle Cenozoic effectively isolated Antarctica thermally by decoupling the warmer subtropical gyres from the Antarctic continent (Kennett, 1977). This increasing isolation, in turn, may have assisted in the development of Antarctic glaciation and ultimately in the formation of major ice-sheets. The climatic change included the cooling of waters surrounding the continent, extensive seasonal sea-ice production, and wind-driven upwelling of nutrient-rich intermediate waters that have a profound effect on biogenic productivity in the Southern Ocean.

The most important components of modern Southern Ocean circulation are the Antarctic Circumpolar Current (ACC) and Antarctic (Weddell Sea) Bottom Water (AABW, WSBW). The $A C C$ is largely wind driven but extends to the deep seafloor, where it is often erosional. The ACC axis coincides closely with the Polar Front (Antarctic Convergence) and marks the boundary in modern sediments between a Subantarctic calcareous and a southern siliceous biofacies, which characterizes the Antarctic water masses (Goodell, 1973). The ACC is presumed to be a barrier to the southward migration of warm surface waters, so that it thermally isolates the continent. South of the ACC axis, the carbonate compensation depth is generally shallow $(<\sim 500 \mathrm{~m})$, so that calcareous sediments are rarely found on the deep seafloor (Kennett, 1966; Echols and Kennett, 1973; Barker, Kennett, et al., 1988a, 1988b).

The Weddell Sea is of particular importance because it is probably the major source region for AABW (Deacon, 1937), a critical component of the world's thermohaline circulation. Modern WSBW, the densest variety of AABW, is considered to be formed mostly in the southern Weddell Sea (Deacon, 1963; Gordon, 1971), by modification of the ambient Warm Deep Water by (1) the extraction of fresh sea-ice by freezing, to leave a cold brine, and (2) supercooling beneath the floating Ronne and Filchner Ice Shelves (Seabrooke et al., 1971; Gill, 1973; Foster and Middleton, 1979, 1980; Weiss et al., 1979; Foldvik and Gammelsrod, 1988). WSBW reinforces AABW from beneath and becomes a western boundary undercurrent flowing north and east. Most recirculates within the cyclonic (clockwise) Weddell Gyre (Foster and Carmack, 1976; Deacon, 1979; Treshnikov et al., 1980; Gordon et al., 1981), but some flows north through topographic deeps beneath the ACC, into the deep basins of much of the world ocean (Georgi, 1981; Mantyla and Reid, 1983). Because of the modern processes involving formation of deep waters, surface to deep waters of the Antarctic are similar in temperature and other physical properties, and there is little vertical structure. Beneath a seasonally variable surface layer, extending 20-50 m, three water masses dominate the Weddell Sea (Foster and Carmack, 1976): 
1. Winter Water, characterized by potential temperature $\phi=$ $-1.8^{\circ}$ to $-1.6^{\circ} \mathrm{C}$ and salinities $\mathrm{S}=34.36 \%$ to $34.52 \%$; below this is

2. Warm Deep Water $\phi=0^{\circ}$ to $0.8^{\circ} \mathrm{C}$ and $\mathrm{S}=34.64 \%$ to $34.72 \%$; below this is

3. Antarctic Bottom Water $\phi=-0.8^{\circ}$ to $0^{\circ} \mathrm{C}$ and $\mathrm{S}=$ $34.64 \%$ to $34.68 \%$.

The modern Weddell Sea environment is marked by bordering ice shelves to the south and west and by the vast winter extent of sea-ice that covers almost all of the region except for the Weddell Sea polynya to the east. The Weddell Sea lies south of the Antarctic Divergence, a major site of oceanic upwelling and the principal site of siliceous productivity and sedimentation.

The Weddell Sea environment has undergone fundamental changes through the Cenozoic; many of the parameters that collectively define the modern environment did not exist in the geologic past. Our data show a very different pre-Oligocene Antarctic oceanographic and terrestrial regime, with relatively warm high-latitude surface waters, a more gentle and continuous meridional temperature gradient, thermospheric deep-sea circulation, continental glaciation lacking ice-sheets, continental vegetation, and warmer marine assemblages with higher diversity of calcareous forms. The processes of formation of deep waters would have been quite different; but in what way? Understanding the interrelations between developing environmental characteristics, and their broader global significance, was one of the primary objectives of Leg 113.

High-latitude cooling did not proceed uniformly but was marked by discrete steps (Kennett, 1977; Berger et al., 1981). An understanding of the climatic evolution of Antarctica and the surrounding Southern Ocean during the late Phanerozoic is central to studying the development of global climate and circulation. Previous drilling in Antarctic and Subantarctic areas (DSDP Legs $28,29,35,36$, and 71) provides an important basis for our current understanding of the evolution of the Southern Ocean and of the climatic and cryospheric development of the Antarctic continent. With this greater insight into the Antarctic came new questions that required additional drilling and scientific research. Leg 113 (5 January-11 March 1987) was the first of four (ODP Legs 113, 114, 119, and 120) new scientific ocean drilling expeditions in the South Atlantic and Indian sectors of the Southern Ocean to provide new material for advancement of knowledge of Antarctic paleoceanographic and paleoclimatic history. This information is complemented by the CIROS-I drilling on the continental margin of the Ross Sea (Barrett et al., 1989).

During Leg 113, nine sites (Sites 689-697) were drilled using JOIDES Resolution in the Weddell Sea (Figs. 1 and 2; Table 1). These sites form a depth transect for studies of vertical water mass stratification, climatic evolution and paleoceanographic history of Antarctica, and the surrounding ocean during the late Mesozoic and Cenozoic. They represent contrasting environments: open-ocean pelagic sedimentation on Maud Rise (Sites 689 and 690), hemipelagic and terrigenous sediments on the East Antarctic continental margin (Sites 691-693), a turbiditic sequence in the deep Weddell Basin (Site 694), and hemipelagic and biogenic sediments on the South Orkney microcontinent (Sites 695-697). Of particular importance was the recovery of sediments from Sites 689 and 690 (Maud Rise; $65^{\circ} \mathrm{S} ; \sim 700 \mathrm{~km}$ north of East Antarctica), the first composite Late Cretaceous to Quaternary pelagic sequence from Antarctic waters. This sequence also represents the southernmost available record of calcareous deep-sea sediments. Biosiliceous facies progressively replaced carbonates during the middle to late Cenozoic, reflecting sequential cooling of the Antarctic water mass. These sites provide the southernmost anchor for Atlantic biostratigraphy, bio-

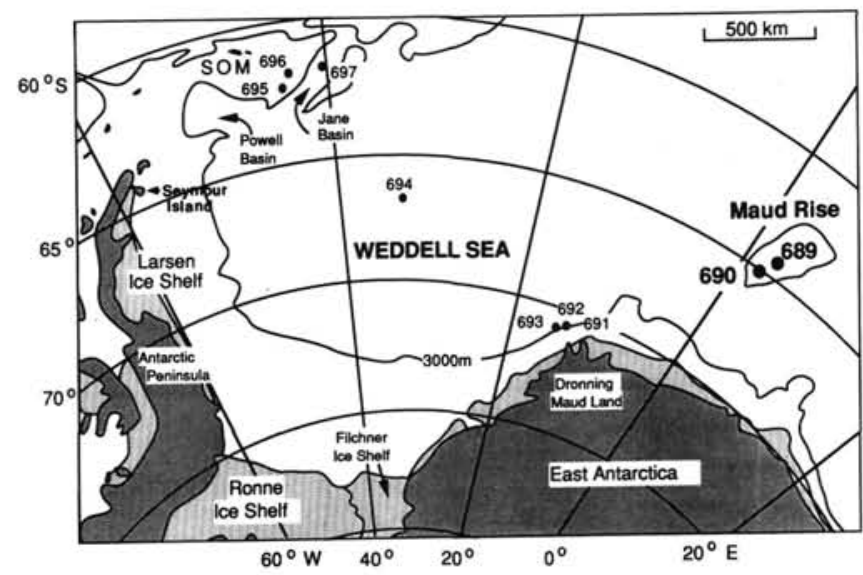

Figure 1. Location of Leg 113 Sites (Sites 689-697) in the Weddell Sea All sites lie in the present-day Antarctic water mass, south of the polar front (from Robert and Maillot, this volume).

geography, and isotopic stratigraphy; the first sequence from the Antarctic that provides a late Mesozoic-Paleogene calcareous nannofossil, and benthic and planktonic foraminiferal, biostratigraphy.

Previously, the most southern calcareous sequences were from the Falkland Plateau, $1500 \mathrm{~km}$ to the north, and lower Paleogene sediments from the northern part of the Antarctic Peninsula (Seymour Island) contain calcareous assemblages, but these were deposited at neritic depths. We were provided with the first opportunity to examine the evolution of Antarctic deep water formation during the Paleogene and the influence of the changing climatic conditions on the structure of the Antarctic water column including seasonality in the region.

Principal questions addressed by drilling during Leg 113 have been described in Barker et al. (1988b) and Barker, Kennett, et al. (1988a). One of the central and yet most controversial relates to the development of the Antarctic cryosphere. Three general models have been proposed: (1) that the cryosphere has exhibited a more or less progressive evolutionary development, i.e., step-like since the Eocene (e.g., Kennett, Houtz, et al., 1975; Shackleton and Kennett, 1975; Hayes, Frakes, et al., 1975; Miller et al., 1987a); (2) that a major, permanent ice-sheet had formed on Antarctica by at least the earliest Oligocene and probably earlier (Matthews and Poore, 1980); (3) that the ice-sheets have undergone long-term instability as late as the late Neogene and at times almost completely disappeared (e.g., Webb et al., 1984; Harwood, 1986). No consensus exists relative to the amount of ice accumulation and the permanency of ice-sheets at particular times in the geologic past, although there is general agreement about the principal times of climatic change (for references, see Stott et al., this volume; Kennett and Stott, this volume; Thomas, this volume; and Miller et al., 1987a). The processes that led to the development of the Antarctic cryosphere during the Cenozoic also continue to be debated (Oglesby, 1989).

These debates have important implications with regard to the understanding of global climatic evolution. Sea level has undergone major fluctuations during the Cenozoic (Vail et al., 1977; Pitman, 1978; Haq et al., 1987). Interpretation of the oxygen isotopic records for paleotemperature data is based on assumptions about the volume of major ice accumulations on the polar continents at times in the past. It is unclear, however, when such accumulations of ice began to affect the oxygen isotopic record and sea level. For example, the oxygen isotopic record has been interpreted by a number of workers to suggest that substantial 


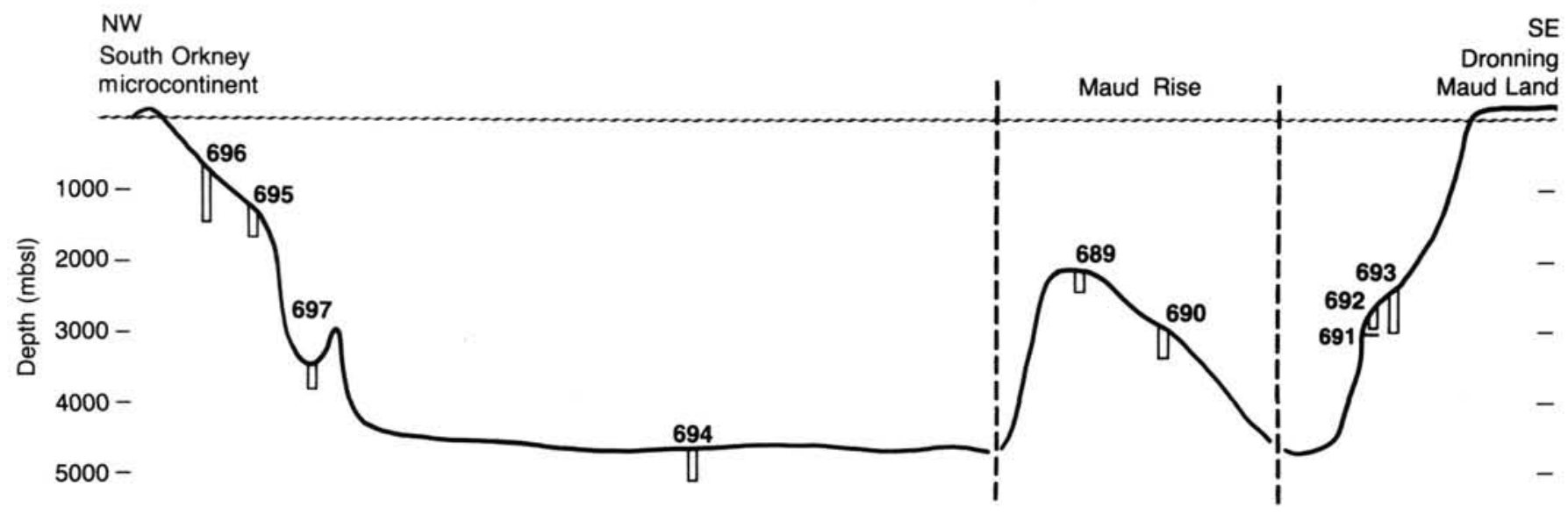

Figure 2. Schematic northwest-southeast transect across the Weddell Sea showing the relative position and depth distribution of Leg 113 sites. The location of Maud Rise has been projected to the west (see Fig. 1) (from Barker, Kennett, et al., 1988). mbsl = meters below sea level.

Table 1. Leg 113 site location and coring summary.

\begin{tabular}{|c|c|c|c|c|c|c|c|c|c|}
\hline Hole & $\begin{array}{c}\text { Date } \\
\text { (1987) }\end{array}$ & Latitude & Longitude & $\begin{array}{l}\text { Water } \\
\text { depth } \\
\text { (m) }\end{array}$ & $\begin{array}{l}\text { Penetration } \\
\text { (m) }\end{array}$ & $\begin{array}{l}\text { No. of } \\
\text { cores }\end{array}$ & $\begin{array}{l}\text { Cored } \\
(\mathrm{m})\end{array}$ & $\begin{array}{l}\text { Recovered } \\
\text { (m) }\end{array}$ & $\begin{array}{c}\text { Recovery } \\
(\%)\end{array}$ \\
\hline $689 \mathrm{~A}$ & Jan. $15-16$ & $64^{\circ} 31.01^{\prime} \mathrm{S}$ & $3^{\circ} 06.00^{\prime} \mathrm{E}$ & 2080 & 11.8 & 1 & 9.5 & 9.4 & 98.4 \\
\hline 689B & $16-18$ & $64^{\circ} 31.01^{\prime} \mathrm{S}$ & $3^{\circ} 06.00^{\prime} \mathrm{E}$ & 2080 & 297.3 & 33 & 297.3 & 229.4 & 77.2 \\
\hline $689 \mathrm{C}$ & 18 & $64^{\circ} 31.01^{\prime} \mathrm{S}$ & $3^{\circ} 06.03^{\prime} \mathrm{E}$ & 2080 & 27.6 & 3 & 27.6 & 20.5 & 74.4 \\
\hline 689D & $18-19$ & $64^{\circ} 31.01^{\prime} \mathrm{S}$ & $3^{\circ} 06.03^{\prime} \mathrm{E}$ & 2080 & 133.8 & 12 & 115.7 & 116.0 & 100.0 \\
\hline $690 \mathrm{~A}$ & $19-20$ & $65^{\circ} 09.63^{\prime} \mathrm{S}$ & $1^{\circ} 12.30^{\prime} \mathrm{E}$ & 2914 & 9.9 & 1 & 7.7 & 9.9 & 128.0 \\
\hline $690 \mathrm{~B}$ & $20-21$ & $65^{\circ} 09.63^{\prime} \mathrm{S}$ & $1^{\circ} 12.30^{\prime} \mathrm{E}$ & 2914 & 213.4 & 25 & 213.4 & 214.6 & 100.5 \\
\hline $690 \mathrm{C}$ & $21-23$ & $65^{\circ} 09.62^{\prime} \mathrm{S}$ & $1^{\circ} 12.29^{\prime} \mathrm{E}$ & 2914 & 321.2 & 24 & 200.6 & 185.6 & 88.3 \\
\hline 691A & $25-26$ & $70^{\circ} 44.54^{\prime} \mathrm{S}$ & $13^{\circ} 48.66^{\prime} \mathrm{W}$ & 3035 & 0.1 & 1 & 0.1 & 0.1 & 100.0 \\
\hline 691B & 26 & $70^{\circ} 44.64^{\prime} \mathrm{S}$ & $13^{\circ} 48.56^{\prime} \mathrm{W}$ & 3038 & 1.7 & 1 & 0 & 0 & 0 \\
\hline $691 \mathrm{C}$ & 26 & $70^{\circ} 44.58^{\prime} \mathrm{S}$ & $13^{\circ} 48.68^{\prime} \mathrm{W}$ & 3025 & 12.7 & 1 & 0 & 0 & 0 \\
\hline $692 \mathrm{~A}$ & 26 & $70^{\circ} 43.45^{\prime} \mathrm{S}$ & $13^{\circ} 49.21^{\prime} \mathrm{W}$ & 2880 & 6.7 & 1 & 6.7 & 0.7 & 10.0 \\
\hline 692B & $26-30$ & $70^{\prime} 43.43^{\prime} \mathrm{S}$ & $13^{\circ} 49.20^{\prime} \mathrm{W}$ & 2875 & 97.9 & 13 & 97.9 & 29.3 & 30.0 \\
\hline $693 \mathrm{~A}$ & Jan. 30-Feb. 5 & $70^{\circ} 49.89^{\prime} \mathrm{S}$ & $14^{\circ} 34.41^{\prime} \mathrm{W}$ & 2359 & 483.9 & 51 & 483.9 & 213.5 & 44.1 \\
\hline 693B & Feb. 5-6 & $70^{\circ} 49.89^{\prime} \mathrm{S}$ & $14^{\circ} 34.46^{\prime} \mathrm{W}$ & 2359 & 403.1 & 19 & 167.4 & 92.2 & 55.1 \\
\hline $694 \mathrm{~A}$ & $9-10$ & $66^{\circ} 50.83^{\prime} \mathrm{S}$ & $33^{\circ} 26.79^{\prime} \mathrm{W}$ & 4653 & 9.8 & 1 & 9.8 & 9.8 & 100.0 \\
\hline 694B & $10-14$ & $66^{\circ} 50.84^{\prime} \mathrm{S}$ & $33^{\circ} 26.83^{\prime} \mathrm{W}$ & 4653 & 179.2 & 24 & 179.2 & 67.1 & 37.4 \\
\hline $694 \mathrm{C}$ & $14-18$ & $66^{\circ} 50.82^{\prime} \mathrm{S}$ & $33^{\circ} 26.76^{\prime} \mathrm{W}$ & 4653 & 391.3 & 23 & 212.1 & 71.7 & 33.8 \\
\hline $695 \mathrm{~A}$ & $20-23$ & $62^{\circ} 23.48^{\prime} \mathrm{S}$ & $43^{\circ} 27.10^{\prime} \mathrm{W}$ & 1305 & 345.1 & 42 & 341.1 & 254.4 & 73.7 \\
\hline 696A & $23-24$ & $61^{\circ} 50.95^{\prime} \mathrm{S}$ & $42^{\circ} 55.98^{\prime} \mathrm{W}$ & 650 & 103.0 & 12 & 106.0 & 58.3 & 55.0 \\
\hline 696B & Feb. 24-Mar. 2 & $61^{\circ} 50.96^{\prime} \mathrm{S}$ & $42^{\circ} 56.00^{\prime} \mathrm{W}$ & 650 & 645.6 & 62 & 569.0 & 156.7 & 27.5 \\
\hline 697A & Mar. 3-4 & $61^{\circ} 48.63^{\prime} \mathrm{S}$ & $40^{\circ} 17.27^{\prime} \mathrm{W}$ & 3481 & 20.9 & 3 & 28.1 & 26.6 & 94.7 \\
\hline 697B & $4-7$ & $61^{\circ} 48.63^{\prime} \mathrm{S}$ & $40^{\circ} 17.75^{\prime} \mathrm{W}$ & 3483 & 322.9 & 32 & 304.9 & 188.3 & 61.7 \\
\hline
\end{tabular}

${ }^{\mathrm{a}}$ Depth $=$ bottom felt $(\mathrm{m}$, drill pipe from the dual elevator stool $)-11.1 \mathrm{~m}$.

ice-sheets developed at times during the Oligocene (Miller and Fairbanks, 1983; Shackleton et al., 1984; Miller and Thomas, 1985; Wise et al., 1985; Murphy and Kennett, 1986). Such conclusions are based upon isotopically derived bottom-water temperatures cooler than those of the present oceans. Other workers have employed sedimentary criteria from the continental margins as evidence for the existence of major Oligocene icesheets (e.g., Shipboard Scientific Party, Leg 119, 1988; Barrett et al., 1989), although the extent and permanency of such possible ice-sheets are open to question.

The purpose of this contribution is to summarize principal results of Leg 113 related to the latest Cretaceous through Cenozoic paleoclimatic, paleoceanographic, and biogeographic development of the Weddell Sea region. Details of the results summarized here are set forth in other chapters and in Barker, Kennett, et al. (1988a), and the reader is referred to these sources. We do not attempt to include extensive referencing of the pertinent outside literature, since this is largely provided in each chapter. Nor do we summarize the results of individual sites, since this is already given in Barker, Kennett, et al. (1988a). The chronostratigraphic time scale of Berggren et al. (1985a, b, c) has been used consistently throughout this report.

We consider that the scientific investigations resulting from Leg 113 have been very successful. Much was learned, but many problems remain and additional questions have been raised. Contrasting ideas have arisen over the interpretations of the recovered sequences, and we attempt to point these out in the discussions. Many of the major questions posed to Leg 113 scientists cannot be solved by a single approach. An integrated approach is needed using a broad array of sedimentologic, micropaleontologic, and geochemical parameters. Further, the results from Leg 113 will need to be integrated with the results derived from the three later Antarctic ODP expeditions (Legs 114, 119, and 120). Clearly, given the limitations of data, some conclusions formulated by studies of Leg 113 materials will need modification as a result of these other expeditions. 


\section{SUMMARY OF WEDDELL SEA LATEST CRETACEOUS-CENOZOIC PALEOCLIMATIC/ PALEOCEANOGRAPHIC HISTORY}

\section{Paleoclimatology-Paleoceanography: Latest Cretaceous}

During the Maestrichtian, a range of parameters, including oxygen isotopes, clay mineralogy, and characteristics of planktonic microfossil assemblages at Sites 689 and 690, indicates temperate to cool subtropical climates with high seasonality in Antarctica and its vicinity. Oxygen and carbon isotopic offsets between various planktonic and benthic foraminiferal species suggest the presence of a well-developed seasonal thermocline. These gradients suggest high seasonality in the surface waters near Antarctica and hence probably on the continent itself. Leg 113 data provide no evidence of cryospheric activity in the Antarctic region. A general increase of $\sim 0.75 \% 0-1.2 \%$ in $\delta^{18} \mathrm{O}$ values in foraminifers during the Maestrichtian indicates a cooling trend in both surface and intermediate waters (Barrera and $\mathrm{Hu}$ ber, this volume) and is similar to that reported for the Maestrichtian of Seymour Island, Antarctica (Barrera et al., 1987). Both sequences also exhibit a rapid increase in $\delta^{18} \mathrm{O}$ near the beginning of the late Maestrichtian $(\sim 69.9 \mathrm{Ma})$ preceded by a distinct decrease in $\delta^{13} \mathrm{C}$. In the absence of sea-ice during the Maestrichtian, it is unclear if the Antarctic represented a major source of deep waters to the world ocean. The interpretation of the stable isotopic composition of Maestrichtian foraminifers in the two Maud Rise sites led Barrera and Huber (this volume) to suggest that deep waters of the South Atlantic were of Antarctic origin, as Barrera et al. (1987) had previously inferred based on studies of an Upper Cretaceous sequence on Seymour Island. The benthic foraminiferal oxygen isotopic data from Maud Rise, however, are unclear because cooler isotopic temperatures are recorded at the shallow (Site 689), rather than the deeper site (Site 690). On the other hand, isotopic temperatures are also lower for planktonic foraminifers and bulk carbonate at Site 689 , when no difference should occur in surface-water temperatures at such nearby sites.

Clay minerals in Maestrichtian sediments are dominated by smectite and are considered to represent evidence for warm continental climates and strong hydrolysis resulting from alternating wet and dry seasons (Robert and Maillot, this volume).

Planktonic and benthic foraminiferal and calcareous nannofossil assemblages of Maestrichtian age in the Weddell Sea are similar to those previously reported from the Falkland Plateau and other high southern latitudes (Huber, this volume; Pospichal and Wise, this volume, chapter 30 ). These assemblages form a distinct southern biogeographic planktonic province. A relatively cool aspect to this province is indicated by low diversity (maximum of $\sim 16$ planktonic foraminiferal species per sample; total of 24 for Maestrichtian), an absence of forms known from lower latitudes and the presence of southern endemic taxa.

An apparently complete uppermost Cretaceous-lower Tertiary $(\mathrm{K} / \mathrm{T})$ calcareous sequence at Site 690 has provided vital information about paleoclimatic and paleoceanographic changes before, during, and after the K/T boundary in the Weddell Sea. Stable isotopic data indicate that significant climatic and oceanographic changes occurred prior to the $\mathrm{K} / \mathrm{T}$ mass extinction event (Stott and Kennett, this volume, chapter 47; Pospichal and Wise, this volume, chapter 32) and an enrichment in iridium (Michel et al., this volume) at the $\mathrm{K} / \mathrm{T}$ boundary $(66.4 \mathrm{Ma})$. This supports the observations of previous workers (e.g., Askin, 1989; Keller, 1989). An oxygen isotopic decrease of up to $\sim 0.7 \%$ representing an apparent warming of $\sim 3^{\circ} \mathrm{C}$ of surface and intermediate waters, is recorded in planktonic and benthic foraminifers between 66.9 and $66.6 \mathrm{Ma}$ (Fig. 3). In spite of the magni- tude of this short-term warming of Weddell Sea waters, there were no significant changes in the planktonic microfossil assemblages. This, in turn, suggests that the warming event neither affected the structure of the thermocline nor caused any significant changes in the marine biotic environment of the Weddell Sea (Stott and Kennett, this volume, chapter 47).

This negative isotopic excursion was short-lived and was immediately followed (Fig. 3) by a positive excursion of similar magnitude between $66.6 \mathrm{Ma}$ (latest Cretaceous) and $\sim 66.3 \mathrm{Ma}$ (earliest Paleocene) recorded in both planktonic and benthic foraminifers (Stott and Kennett, this volume, chapter 34). This positive excursion began $200 \mathrm{k} . \mathrm{y}$. prior to the $\mathrm{K} / \mathrm{T}$ boundary and coincided with a general increase (from 0.2 to $0.8 \mathrm{~g} / \mathrm{cm}^{2}$ / k.y.) in the accumulation rate of calcium carbonate. Surface waters seem to have cooled at the same time at lower latitudes (Zachos and Arthur, 1986), indicating that this event was more than local. Paleoclimatic changes, such as those clustered very close to the K/T boundary, are atypical for the interval beginning $1 \mathrm{~m} . \mathrm{y}$. prior to and $2 \mathrm{~m}$.y. following the boundary.

A decrease in isotopic gradients between several planktonic foraminiferal species suggests that the thickness and strength of the thermocline was reduced in response to the decrease of seasurface temperature at the end of the Cretaceous. Alternatively there may have been changes in the seasonal temperature contrasts in the Antarctic (Stott and Kennett, this volume, chapter 34). Changes in the seasonal thermocline may, in turn, have had a significant effect on the Antarctic trophic system, although there is little evidence of major faunal change that occurred during the cooling interval that preceded the $\mathrm{K} / \mathrm{T}$ boundary. If, on the other hand, the rapid warming and cooling events that preceded the $\mathrm{K} / \mathrm{T}$ boundary were global, the question arises as to whether there was a relationship between these changes and the $\mathrm{K} / \mathrm{T}$ boundary mass extinction event. Clearly the cooling itself did not cause the extinctions, but the environmental changes imposed on the marine and terrestrial biota may have predisposed them to extinction; with extinction and mass mortality resulting from a superimposed catastrophic event (Stott and Kennett, this volume, chapter 34 ).

The $\delta^{13} \mathrm{C}$ record from Maud Rise also indicates that significant paleoceanographic changes immediately preceded the $\mathrm{K} / \mathrm{T}$ boundary mass extinction event (Fig. 4). A major positive $\delta^{13} \mathrm{C}$ excursion occurred during the interval 200-300 k.y. before the boundary, involving a shift of planktonic and benthic $\delta^{13} \mathrm{C}$ of $\sim 0.5 \% 0-0.75 \%$. This positive carbon isotopic shift is larger than most other similar shifts during the Cenozoic. Changes in $\delta^{13} \mathrm{C}$ of the same magnitude have been recorded at lower latitudes in the Atlantic and Pacific Oceans in uppermost Cretaceous deep-sea sequences (Shackleton et al., 1984; Zachos et al., 1989), indicating an ocean wide change in the total dissolved inorganic carbon (TDC) reservoir. The magnitude of this shift, and its association with oxygen isotopic cooling of surface waters, suggests that it may have been linked to global climate change through feedback loops in the carbon cycle (Stott and Kennett, this volume, chapter 47). For example, the isotopic changes may have been caused by an increase in burial rate of organic carbon in the oceans, a decrease in atmospheric $\mathrm{pCO}_{2}$, and a resulting reversed greenhouse effect.

In summary, the sequence of events recorded in the Maud Rise sites, in association with similar observations in other parts of the world ocean, clearly show that major changes occurred in the marine environment during the last 200 k.y. of the Cretaceous. Any model that attempts to explain the demise of the oceanic plankton at the end of the Cretaceous should take into consideration the oceanic environmental changes that occurred prior to the mass extinction event. 
$\delta^{18} \mathrm{O}$

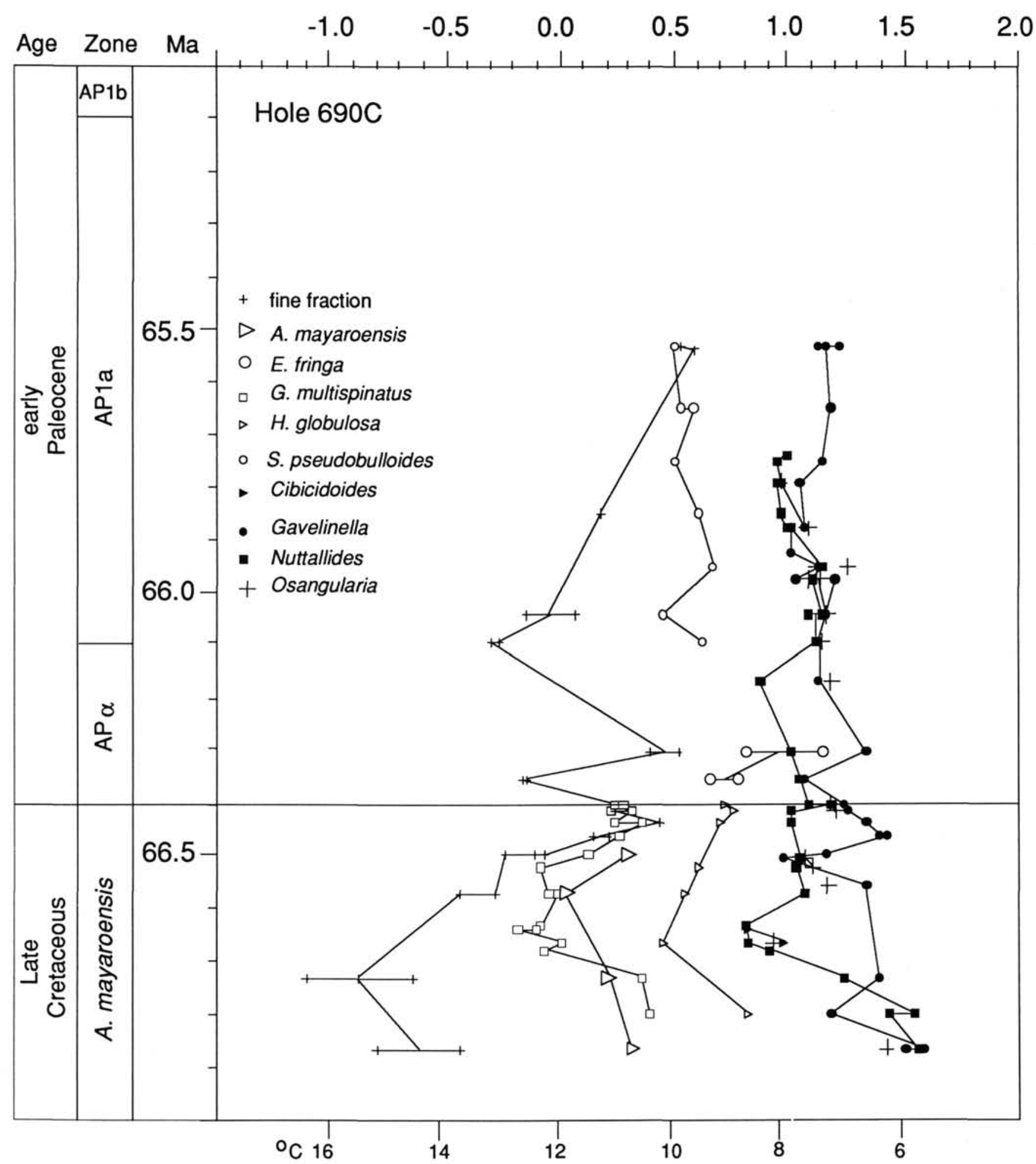

Figure 3. Planktonic and benthic $\delta^{18} \mathrm{O}$ values relative to PDB in Hole $690 \mathrm{C}$, Maud Rise, over the Cretaceous/Tertiary boundary. Planktonic foraminifer values shown by open symbols; benthic foraminifers by solid symbols and cross. Foraminiferal zones (AP) are defined in Stott and Kennett (this volume, chapter 34). (From Stott and Kennett, this volume, chapter 47.) 


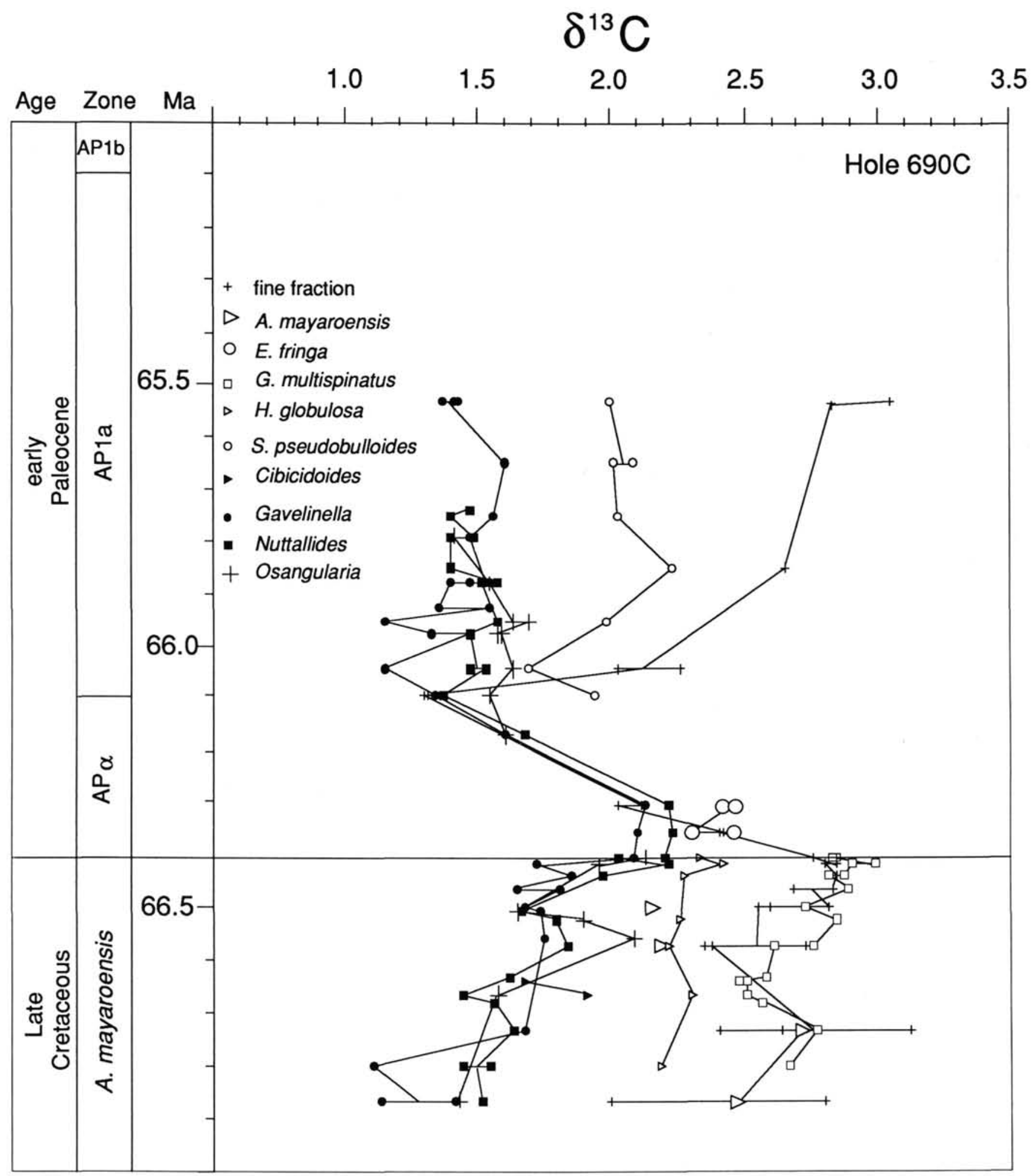

Figure 4. Planktonic and benthic $\delta^{13} \mathrm{C}$ relative to $\mathrm{PDB}$ in Hole 690C, Maud Rise, over the Cretaceous/Tertiary boundary. Planktonic foraminifer values shown by open symbols; benthic foraminifers by solid symbols and cross. Foraminiferal zones (AP) are defined in Stott and Kennett (this volume, chapter 34). (From Stott and Kennett, this volume, chapter 47.) 


\section{The Cretaceous/Tertiary Boundary and Immediate Aftermath}

Moderately detailed studies of the K/T boundary interval in the Weddell Sea were made possible because of the availability in Hole $690 \mathrm{C}$ of a continuous, although highly bioturbated, K/ $\mathrm{T}$ boundary calcareous sequence, the first obtained from the deep-sea Antarctic region. The $\mathrm{K} / \mathrm{T}$ boundary is recognized on the basis of extinctions of Cretaceous planktonic foraminifers (Stott and Kennett, this volume, chapter 47) and calcareous nannofossil species (Pospichal and Wise, this volume, chapter 32) near the top of Chron 29R (Hamilton, this volume). The biostratigraphically defined boundary coincides with a distinct iridium spike at 247.79 mbsf (Michel et al., this volume). Upper Maestrichtian-lowermost Paleocene sediments consist mostly of light-colored nannofossil chalks. Dark brown sediments at the base of the Danian (Zone CP1a) are marked by a relative increase in clay content inferred to result from a decrease in calcareous plankton productivity following the terminal Cretaceous event (Pospichal and Wise, this volume, chapter 30 ). The clays at the $\mathrm{K} / \mathrm{T}$ boundary exhibit slightly higher abundances of probably volcanogenic smectite, although these are considered to be secondarily derived rather than representing evidence of increased volcanic activity at that time (Robert and Chamley, in press).

In contrast to the massive changes in calcareous plankton that occurred at the boundary, the benthic foraminifers exhibit relatively minor changes (Thomas, this volume). The boundary is placed in Hole $690 \mathrm{C}$ by Stott and Kennett (this volume, chapter 47 ) between 247.75 and $247.80 \mathrm{mbsf}$, that interval where major extinctions occurred in Cretaceous planktonic foraminifers and where Paleocene forms began to dominate. Pospichal and Wise (this volume, chapter 32 ) place the boundary slightly lower, between 247.81 and $247.89 \mathrm{mbsf}$ based on the appearance of $\mathrm{Bi}$ antholithus sparsus, which they considered to be the first true Tertiary calcareous nannofossil form to appear in this sequence. This level also coincides well with the beginning of the rise in number of "survivor" taxa and the decline of Cretaceous species. Calcareous nannofossils underwent a sequential change across the boundary: Cretaceous assemblages with a diversity of $\sim 20$ species gave way at the boundary to a "survivor" dominated assemblage ( $\sim 5$ to 6 survivor forms and two Tertiary forms), followed within $35 \mathrm{~cm}$ by the beginnings of a rapid speciation of Tertiary taxa (Pospichal and Wise, this volume, chapter 32).

All Cretaceous calcareous dinoflagellate species ("calcispheres") became extinct at or immediately above the K/T boundary. An assemblage made up of new forms almost immediately evolved and began to flourish in Zone CP1a, making up an important component of the total sediment (Fütterer, this volume). The abundance of calcispheres is highest in the lower Paleocene (CP1b to lower CP2 up to $30 \%$ ), perhaps suggesting that these were opportunistic planktonic forms that were able to evolve rapidly and flourish in new environmental conditions. At almost the same latitude $\left(\sim 66^{\circ} \mathrm{S}\right)$ on Seymour Island, northern Antarctic Peninsula, silicoflagellates exhibit an abrupt extinction at the end of the Cretaceous and a gradual recovery during the early Paleocene (Harwood, 1988). In contrast, diatom diversity was largely unaffected by the $\mathrm{K} / \mathrm{T}$ boundary events that devastated the other planktonic groups, although diatom resting spore abundances significantly increased (Harwood, 1988). Harwood (1988) has suggested that resting spore formation added to the survival of the diatoms. Pollen and spores from the Seymour Island sequence record little change and suggest that there was no abrupt event in the terrestrial vegetation across the Cretaceous/Tertiary boundary for this part of the Antarctic (Askin, 1988). Likewise, most changes in marine invertebrate macrofossils occurred gradually over the $\mathrm{K} / \mathrm{T}$ boundary interval in the
Seymour Island sequence. These took place over an interval of as much as $50 \mathrm{~m}$ with no single extinction horizon (Zinsmeister et al., in press).

Continued changes in the $\delta^{13} \mathrm{C}$ of microfossils across the $\mathrm{K} / \mathrm{T}$ boundary in Hole 690C (Fig. 4) indicate further major changes in the distribution of carbon in the oceans at this time, and of the global carbon budget. Benthic $\delta^{13} \mathrm{C}$ values were at their highest levels at the boundary and then began to decrease $\sim 100 \mathrm{k} . \mathrm{y}$. following the boundary (Stott and Kennett, this volume, chapter 47; Stott and Kennett, in press). By 100 k.y. following the boundary, all calcareous planktonic microfossils record a decrease in $\delta^{13} \mathrm{C}$. This is the well-known $\delta^{13} \mathrm{C}$ excursion that occurred in the earliest Paleocene (see Stott and Kennett, this volume, chapter 34 , for extensive references). At the end of this excursion, in the early Paleogene, benthic $\delta^{13} \mathrm{C}$ values were similar to those in the pre-K/T boundary intervals. The negative shift may have resulted from a change in $\delta^{13} \mathrm{C}$ of the oceanic total dissolved carbon reservoir due to reduced organic carbon burial and/or increased organic carbon flux to the oceans. Also of importance at the $\mathrm{K} / \mathrm{T}$ boundary in Hole $690 \mathrm{C}$ was a reduction in the surface-to-deep-water gradient of $\delta^{13} \mathrm{C}\left(\Delta \delta^{13} \mathrm{C}\right)$ of $\sim 0.6 \%$ (Fig. 4). A decrease in this gradient just above the $\mathrm{K} / \mathrm{T}$ boundary is well known from studies in other deep-sea sequences and has been equated with a period of extremely low oceanic primary productivity as a result of the mass extinction of plankton at the K/T boundary (Zachos and Arthur, 1986; Arthur et al., 1987), the so-called "Strangelove Ocean" (Broecker and Peng, 1982; Hsü and McKenzie, 1985). The lowest values of calcium carbonate in Hole $690 \mathrm{C}$ are recorded in the earliest Tertiary zone $(\operatorname{AP} \alpha)$, an interval marked by particularly low $\Delta \delta^{13} \mathrm{C}$. The Maud Rise carbon isotopic data support the previous interpretations of a global reduction in oceanic primary productivity. However, at Hole $690 \mathrm{C}$, the planktonic-benthic $\delta^{13} \mathrm{C}$ gradient $\left(\Delta \delta^{13} \mathrm{C}\right)$ was not totally eliminated as in other regions (Zachos and Arthur, 1986), suggesting that productivity was not diminished in the region as much as in other areas or that the isotopic values at other sites are biased due to the use of mixed assemblages of different planktonic and benthic species.

The isotopic data from the Weddell Sea also suggest that recovery from this extinction episode may have been different from that of other areas. At Hole $690 \mathrm{C}, \Delta \delta^{13} \mathrm{C}$ gradually increased during the $400 \mathrm{k} . \mathrm{y}$. interval following the $\mathrm{K} / \mathrm{T}$ extinction level, leading to the establishment of a normal $\Delta \delta^{13} \mathrm{C}$ gradient by $\sim 66$ Ma (Fig. 4). In other areas, the vertical gradient may not have begun to be reestablished until $400 \mathrm{k} . \mathrm{y}$. following the inferred oceanic productivity collapse at the boundary (Zachos and Arthur, 1986). These results may suggest regional differences in the "Strangelove Ocean," although it has been pointed out by Stott and Kennett (this volume, chapter 47) that the measured isotopic gradients in various sequences may be complicated by disequilibrium effects in the microfossils themselves during the time of the "Strangelove Ocean."

Thomas (this volume) determined that no major extinctions occurred in deep-sea benthic foraminiferal assemblages at a time when primary productivity was surely reduced due to the planktonic extinctions. This is perhaps surprising, considering that food resources for benthic organisms are ultimately derived from the ocean's surface. Thomas (this volume) did note, however, that epifaunal species increased relative to infaunal forms immediately following the $\mathrm{K} / \mathrm{T}$ boundary on Maud Rise, possibly as a result of decreased nutrient supply. The few benthic foraminifers that did disappear at the boundary were largely those considered by Thomas (this volume) to have lived within the sediments (infaunal).

Another paradox is that there was little change in the $\delta^{13} \mathrm{C}$ composition of benthic foraminifers in the $100 \mathrm{k} . \mathrm{y}$. interval immediately following the $\mathrm{K} / \mathrm{T}$ boundary. Stott and Kennett (in 
press) have suggested that this indicated either that there was little change in preformed $\delta^{13} \mathrm{C}$ of deep waters formed in the Antarctic, or that the Antarctic was not an important source of deep waters flowing to the Maud Rise during the earliest Paleocene.

\section{Paleocene Climatic Conditions}

Diverse calcareous planktonic and benthic microfossil assemblages through much of the Paleocene (except the interval following the K/T boundary mass extinction event; Stott and Kennett, this volume, chapter 34 ) reflect the relative warmth of surface and bottom waters close to Antarctica. East Antarctica continued to be a rich source of fine-grained terrigenous sediment during the Paleocene (Barker, Kennett, et al., 1988a). The clay continued to be dominated by smectite, reflecting relative warmth and a predominance of chemical rather than physical weathering on the continent (Robert and Maillot, this volume).

Oxygen isotopic studies of planktonic foraminifers from Maud Rise (Stott et al., this volume) (Fig. 5) indicate that the surfacewater temperatures were lower in the early Paleocene (average of $\sim 9^{\circ}-10^{\circ} \mathrm{C}$ ) than in the Late Cretaceous. Estimates of surfacewater temperatures for the tropical Pacific (Site 577) during the earliest Paleocene were only $\sim 12^{\circ} \mathrm{C}$ (Zachos et al., 1989), remarkably low for such latitudes. Thus the polar to tropical meridional temperature gradient may have been only $\sim 3^{\circ} \mathrm{C}$. However, if the salinities of tropical surface waters were relatively high at that time, this gradient would have been higher than it appears. At middle latitudes of the South Atlantic (Site 527), surface-water temperatures differed little from those of the Antarctic region (Shackleton et al., 1984), indicating the existence of a broad southern oceanographic province and the influence of warm western boundary currents in the Weddell Sea. Calcareous nannofossil assemblages also define broad oceanic biogeographic provinces at this time. Their distribution in the South Atlantic indicates that the Maud Rise was part of a relatively warm surficial water mass that extended northward to at least the Falkland Plateau. Further to the north, on the Rio Grande Rise, there flourished different, warmer Paleocene nannofossil assemblages (Haq et al., 1977; Barker, Kennett, et al., 1988a) suggesting the presence of a meridional temperature gradient.

In the middle part of the Paleocene $(\sim 63 \mathrm{Ma})$, surface waters began to warm (Fig. 5) and the thermocline strengthened in the Weddell Sea area. This represents the beginning of a broad, global warming trend that spanned the late Paleocene and early Eocene (Stott and Kennett, this volume, chapter 34; Kennett and Stott, this volume). Calcareous nannofossil and planktonic foraminiferal assemblages were dominated by high latitude, cooler taxa (Pospichal and Wise, this volume, chapter 30; Stott and Kennett, this volume, chapter 34). However, the calcareous nannofossils also include a low diversity but abundant group of discoasters and sphenoliths. Abundant discoasters and sphenoliths are reliable indicators of warm surface waters (Pospichal and Wise, this volume, chapter 37 ), and the oxygen isotopic evidence in combination with the occurrence of abundant discoasters suggests warm temperate to cool subtropical conditions during the late Paleocene. The presence of discoasters in the Maud Rise sequence enabled Pospichal and Wise (this volume, chapter 37) to directly apply the often-used low-latitude calcareous nannofossil biostratigraphic zonations for the upper Paleocene to lower Eocene intervals (Martini, 1971; Okada and Bukry, 1980). Well-developed oxygen isotopic gradients between several planktonic foraminiferal taxa and benthic foraminifers suggest that the thermocline was well established during the late Paleocene.

The appearance of kaolinite during the earliest Paleocene in relatively low abundance $(5 \%)$ suggests that humidity progressively increased during the Paleocene on East Antarctica. Under warm, humid climatic conditions, hydrolysis causes heavy weathering of parent-rock and the removal of soluble chemical elements in well-drained areas and hence favors the formation of kaolinite in soils (Millot, 1970; Robert and Maillot, this volume). Kaolinite formation is thus favored by increased precipitation and runoff and/or higher relief. In the absence of high tectonic relief in Dronning Maud Land in the early Paleogene (Grikurov, 1982), it is most likely that the kaolinite in the Maud Rise Paleocene formed as a result of slightly increased humidity and precipitation (Robert and Maillot, this volume). The Paleocene at Hole $690 \mathrm{~B}$ is distinguished by the presence of cyclical reddish sediments, the only interval in the Maud Rise sequence to exhibit such colors. The origin of these colored clays is still unclear but probably reflects the climatic conditions of the source area. The rich reddish colors may, for instance, indicate laterite formation (Barker, Kennett, et al., 1988a) and, if so, these were possibly unique to the Paleocene. The presence in Paleocene sediments of nearby Seymour Island of leaf fossils dominated by small-leaved Nothofagus suggests the presence of temperate Nothofagus forests, at least in the area of the northern Antarctic Peninsula (Case, 1988).

\section{Paleocene/Eocene Boundary Event}

Conspicuous paleoenvironmental and biotic changes mark the end of the Paleocene (magnetobiostratigraphically dated at $\sim 57.5 \mathrm{Ma}$ ) as shown by studies of the Maud Rise sequences. At that time, the $\delta^{18} \mathrm{O}$ of planktonic foraminifers (Stott et al., this volume) indicate a surface-water temperature increase of $5^{\circ}$ $7^{\circ} \mathrm{C}$ (Fig. 5) leading to a maximum of Antarctic surface water temperatures $\left(\sim 18^{\circ}-20^{\circ} \mathrm{C}\right)$. This is perhaps the warmest interval of the entire Cenozoic and forms a spike of less than $\sim 200$ k.y. in duration (Stott and Kennett, unpubl. data). Oxygen isotopic temperatures for benthic foraminifers living at intermediate water depths also record this warm spike. The surface to deep water temperature gradient was strongly reduced and indicates that the entire water column became warmer. The presence of the planktonic foraminifers Morozovella during the Paleocene/Eocene transition supports significant warming of surface waters at this time (Stott and Kennett, this volume, chapter 34), since these forms have not been reported from other Paleogene intervals. A peak in discoaster diversity (up to six species) and abundance also coincides with the Paleocene/Eocene transition and the negative $\delta^{18} \mathrm{O}$ peak (Pospichal and Wise, this volume, chapter 37) supporting interpretations of extreme Antarctic warmth. A peak in kaolinite abundance $(20 \%)$ at this time suggests an increase in humidity and precipitation on the Antarctic continent (Robert and Maillot, this volume). Isotopic temperatures of inferred surface-dwelling planktonic foraminifers became very similar between the Antarctic (Maud Rise) and the tropical Pacific (Miller et al., 1987b), indicating a reduction in the meridional temperature gradient at that time (Stott et al., this volume). This inferred reduction in the meridional temperature gradient was associated with a decrease in the grain size of eolian sediments in the tropical Pacific (Owen and Rea, 1985; Miller et al., 1987b) interpreted to be due to a reduction in wind strength (Stott et al., this volume).

The Paleocene/Eocene transition is also associated with a well-known negative shift in the $\delta^{13} \mathrm{C}$ composition of the oceans (Fig. 6; Shackleton et al., 1985; Shackleton, 1987; Miller et al., 1987a). This shift $\left(\sim 1.25 \%_{0}-2 \% 0\right)$, recorded in both planktonic and benthic foraminifers, began during the late Paleocene at about $61 \mathrm{Ma}$ and reached a climax at the Paleocene/Eocene boundary in association with the other events (Fig. 6). The carbon isotopic changes are exhibited equally in both benthic and planktonic foraminifers, and hence no major change occurred in the surface-to-deep water gradient of $\delta^{13} \mathrm{C}$ (Miller et al., 1987a), especially in the deep sea. At this time, the diversity of 


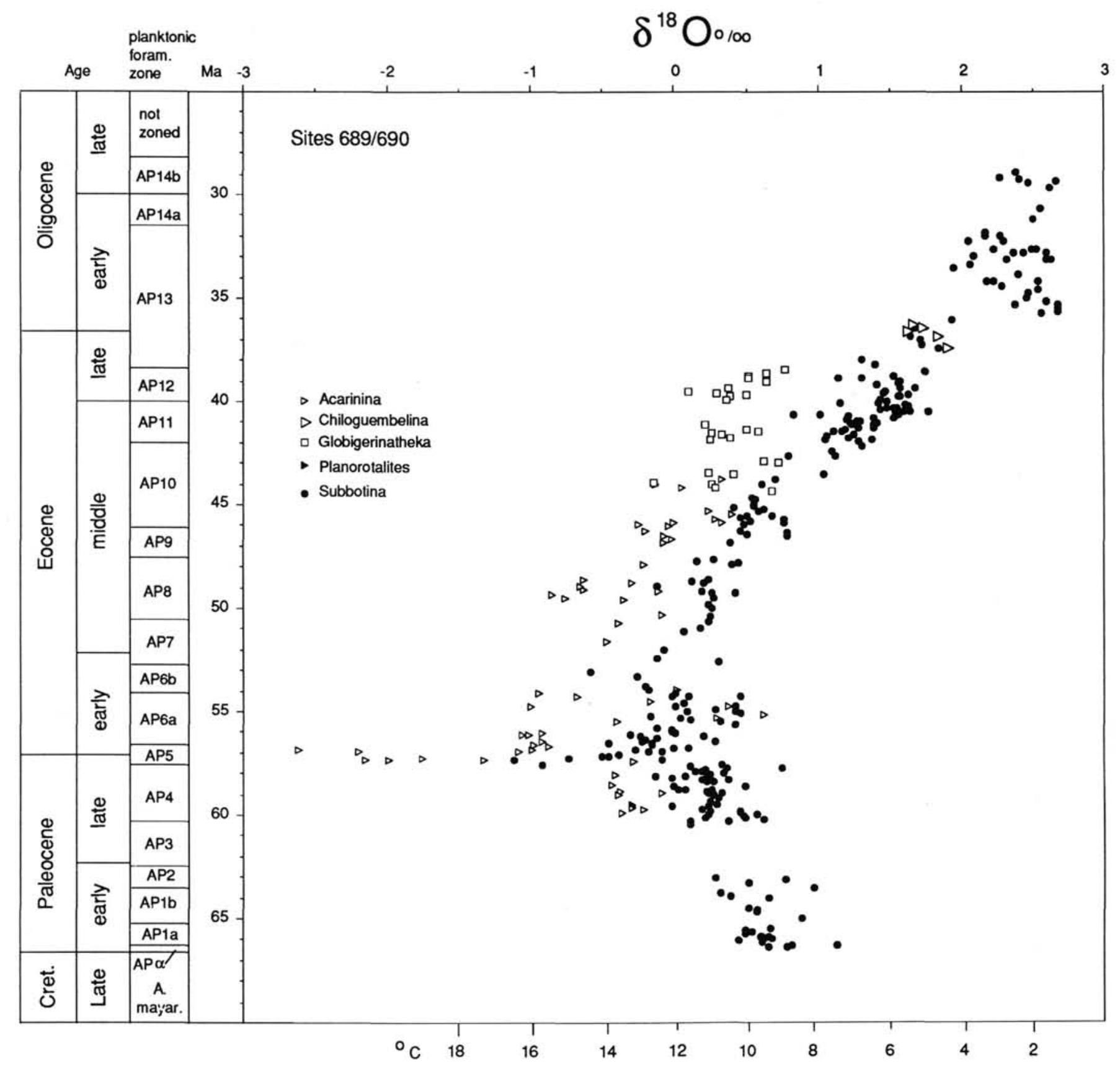

Figure 5. Composite Paleogene oxygen isotopic record relative to PDB of the inferred shallow-dwelling planktonic foraminifers (open symbols) and the inferred deeper-dwelling planktonic forms (closed symbols) for Sites 689 and 690 (Maud Rise). Age scale is that of Berggren et al. (1985a). Foraminiferal zones (AP) are defined in Stott and Kennett (this volume, chapter 34). (After Stott et al., this volume.)

benthic foraminifers on Maud Rise dropped by $\sim 50 \%$, and $35 \%$ of the species became extinct over a period of $<25,000$ years, the most conspicuous extinction in the Antarctic deep sea sequence since at least the Maestrichtian (Thomas, this volume). This extinction level in benthic foraminifers at the Paleocene/Eocene boundary is known to be widespread in the oceans (Beckmann, 1960; Braga et al., 1975; Schnitker, 1979; Tjalsma and Lohmann, 1983; Miller et al., 1987a; Katz and Miller, 1988) and is generally considered to be the most important deep sea benthic extinction in the Late Mesozoic and Cenozoic. The extinction level in the Maud Rise sequence (Thomas, this volume) coincides with a distinct negative spike in both benthic and planktonic $\delta^{18} \mathrm{O}$ and $\delta^{13} \mathrm{C}$ (Stott and Kennett, unpubl. data). Thomas (this volume) showed that the extinction eliminated a greater number of epifaunal relative to infaunal species and suggested that the extinctions resulted from a reduction in oxygen levels due to changes in deep water formation. Infaunal species became dominant. For these and other reasons, Stott et al. (this volume), Kennett and Stott (this volume), and Thomas (this volume) believe that the event at the Paleocene/Eocene boundary resulted either from a switch in formation of deep waters from high to low latitudes, or a major increase in warm-saline deep waters derived from low latitude sources. It is possible that the production of cool intermediate waters at high southern lati- 


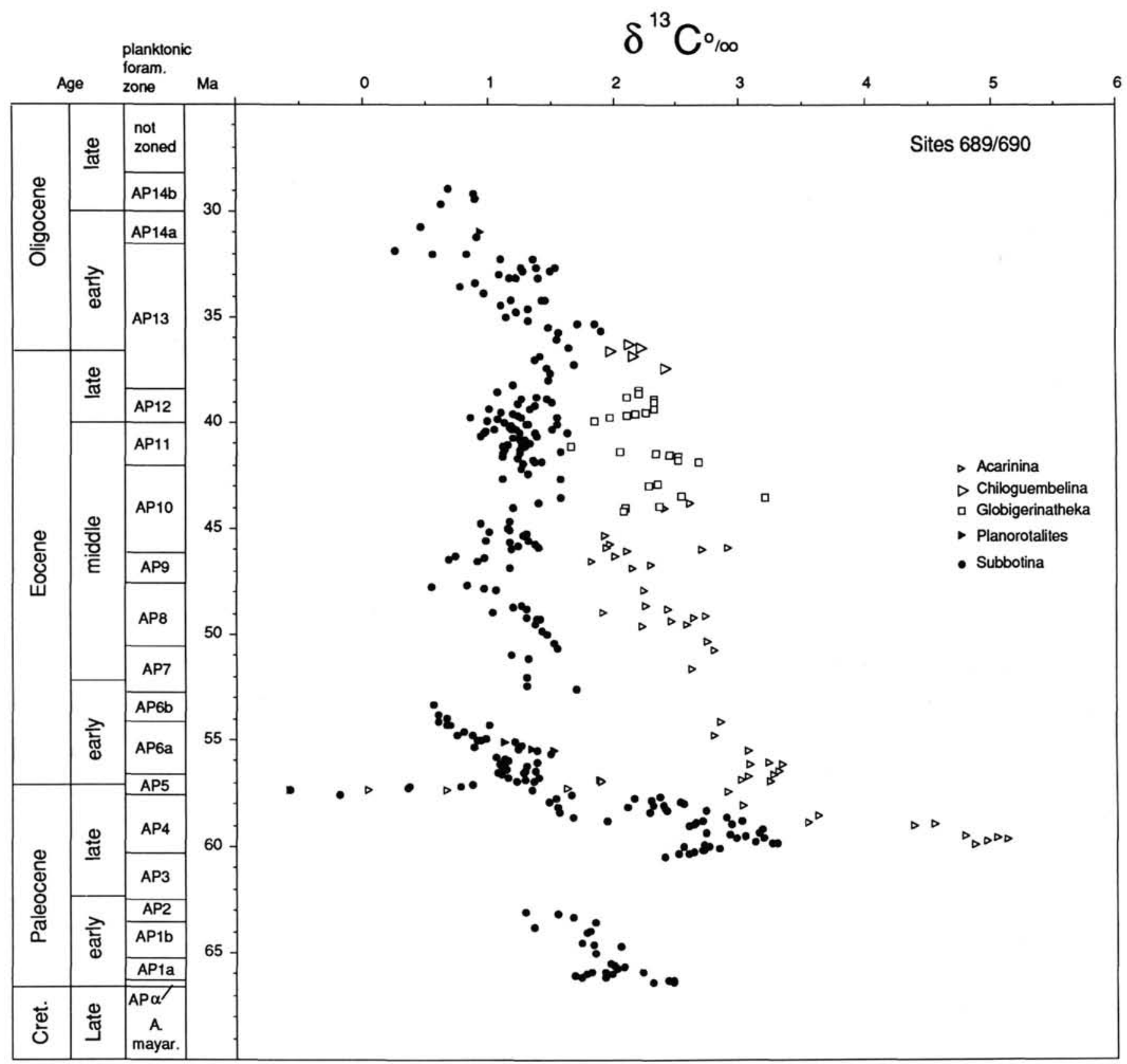

Figure 6. Composite Paleogene carbon isotopic record relative to PDB of the inferred shallow-dwelling planktonic foraminifers (open symbols) and the inferred deeper-dwelling planktonic forms (closed symbols) for Sites 689 and 690 (Maud Rise). Age scale is that of Berggren et al. (1985a). Foraminiferal zones (AP) are defined in Stott and Kennett (this volume, chapter 34). Four stages are shown representing changes in the nature of the Antarctic thermocline (Stott et al., this volume).

tudes may have been turned off briefly at the Paleocene/Eocene boundary as a result of extreme warmth and an infusion of warm waters from lower latitudes. Such waters, being older and warmer, would be lower in dissolved oxygen and would also have higher nutrient concentrations and thus lower $\delta^{13} \mathrm{C}$. This might result in preferential extinction of the epifaunal benthic species rather than the infaunal foraminiferal species, the latter having already adapted to living in low-oxygen environments (Thomas, this volume).

\section{Early Eocene Warmth}

The early Eocene was the time of maximum Cenozoic surface and deep-water temperatures in the Weddell Sea (Stott et al., this volume; Kennett and Stott, this volume) (Figs. 5, 7). Sea-surface temperatures in the Antarctic during much of the Eocene were temperate and at times approached cool subtropical. High northern latitudes were also marked by warm climates during much of the Paleogene, until the early late Eocene (e.g., Wolfe, 1980). One of the current paleoceanographic questions is to explain this exceptional Cenozoic warmth and the subsequent transition to colder climates.

Maximum temperatures recorded by the shallow-dwelling acarininids (planktonic foraminifers) during the early Eocene were between $15^{\circ}$ and $16^{\circ} \mathrm{C}$ during the austral summer season when the thermocline was well developed (Fig. 5). In contrast, the maximum isotopic temperatures inferred for the deep-dwell- 


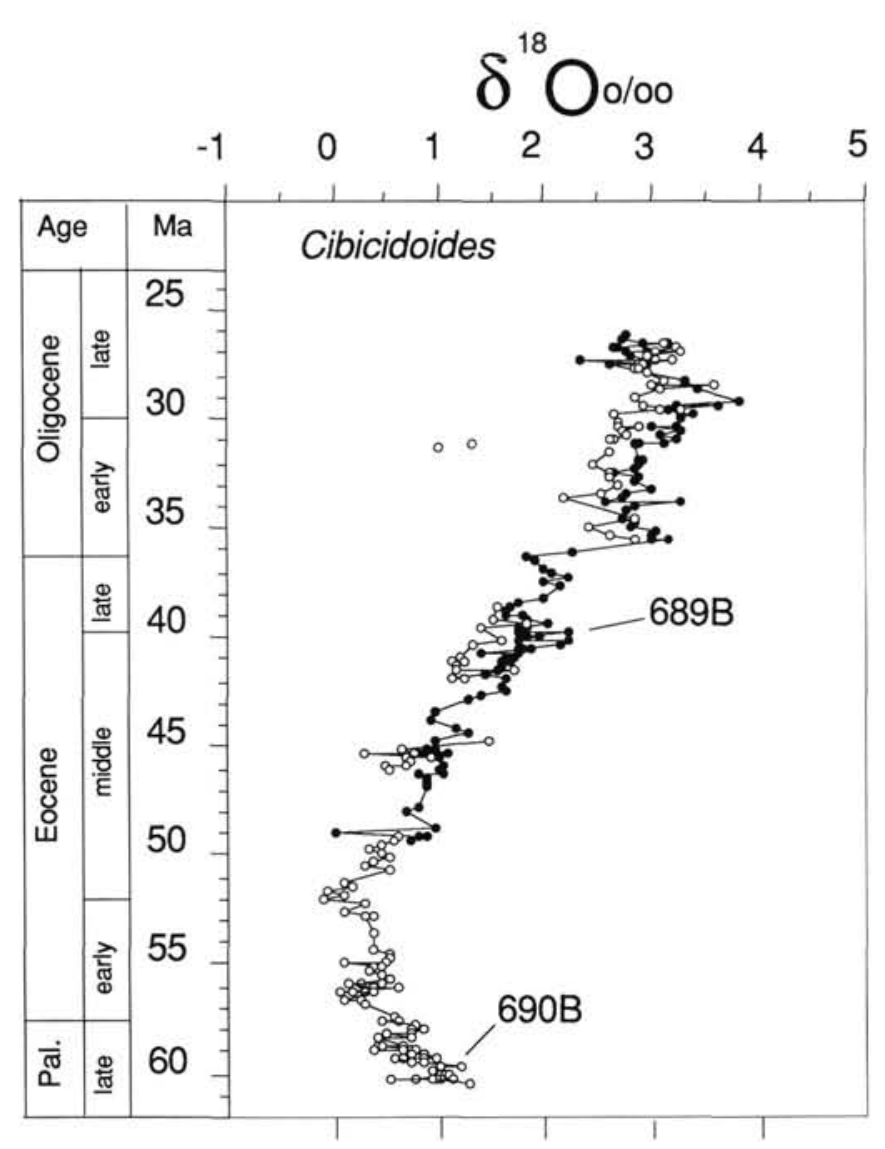

Figure 7. Paleogene oxygen isotopic record relative to PDB for the benthic foraminifer Cibicidoides in Holes 689B (solid circles) and 690B (open circles) (Maud Rise). Age scale is that of Berggren et al. (1985a). (From Kennett and Stott, this volume.)

ing subbotinids (planktonic foraminifers) were between $12^{\circ}$ and $14^{\circ} \mathrm{C}$, similar to values estimated for the benthic foraminifers (Stott and Kennett, this volume, chapter 34). Minimum isotopic temperatures inferred for subbotinids during the Eocene were about $9^{\circ} \mathrm{C}$. Minimum oxygen isotopic temperatures indicated by the subbotinids and benthic foraminifers were assumed by Stott et al. (this volume) to represent approximate winter seasurface temperatures near Antarctica, the possible source of these waters. It is a reasonable assumption that the Antarctic continent lacked any significant ice accumulation during the early Eocene; given this, the minimum isotopic temperatures inferred for surface waters precludes the possibility of sea-ice about Antarctica (Stott et al., this volume).

The alternative assumption, that there was a continental ice sheet, raises the inferred minimum surface water temperature and makes the seasonal presence of sea-ice around the continent even less likely. The range of variation of isotopic temperatures expressed by the planktonic foraminifers suggests a greater thermal stratification during the early Eocene relative to the Paleocene. Furthermore, summer/winter seasonal temperature contrasts were calculated using the $\delta^{18} \mathrm{O}$ values of inferred summer and winter dwelling planktonic foraminifers (Stott et al., this volume). These were $\sim 4^{\circ}-5^{\circ} \mathrm{C}$ in the earliest Eocene and increased to $\sim 6^{\circ}-7^{\circ} \mathrm{C}$ during the late early Eocene. These ranges seem to be conservative when considered for an environment exhibiting long periods of winter darkness and summer light. The diversity of planktonic foraminifers remained relatively high (av- erage $=9$ species; range $=6-11$ species) throughout most of the early to early middle Eocene, reflecting the warm surfacewater temperatures (Stott and Kennett, this volume, chapter 34). However, several forms characteristic of the low latitudes were never present, reflecting the cooler conditions at high latitudes. The late Paleocene-early Eocene interval is marked by shortlived benthic foraminiferal assemblages. This suggests that deep water environments were more unstable at that time than earlier or later (Thomas, this volume).

A wide range of $\delta^{13} \mathrm{C}$ values within the planktonic foraminifers (shallow and deep dwellers; Fig. 6) also supports the conclusion of a well-developed thermocline and high seasonal contrasts during the early Eocene. This gradient began to decrease beginning in the late early Eocene, suggesting either a decrease in the strength of the thermocline or reduced cycling, thereby reducing the vertical $\Delta \delta^{13} \mathrm{C}$ (Stott et al., this volume).

\section{Middle Eocene: Beginning of Climatic Cooling}

Average sea-surface temperatures over Maud Rise remained warm during the middle Eocene, never lower than $\sim 8^{\circ}-9^{\circ} \mathrm{C}$ (Fig. 5). Such warm temperatures would indicate a general absence of seasonal sea-ice in the vicinity of Maud Rise (Stott et al., this volume). At the beginning of the middle Eocene (52 $\mathrm{Ma})$, the maximum inferred summer surface water temperature was $\sim 14^{\circ} \mathrm{C}$ and the minimum winter temperature was $\sim 10^{\circ} \mathrm{C}$. By $45 \mathrm{Ma}$ (middle middle Eocene), temperatures had decreased to $\sim 12^{\circ}$ and $\sim 8^{\circ} \mathrm{C}$, respectively (Fig. 5 ). The thermal maximum of the early Eocene (Fig. 7) ended with the beginning of a long-term cooling trend in surface and deep waters at high latitudes at about $52 \mathrm{Ma}$ (Shackleton and Kennett, 1975; , Shackleton et al., 1984; Oberhänsli et al., 1984; Stott et al., this volume; Kennett and Stott, this volume). The cooling trend continued through the middle and late Eocene with no apparent reversals, and it is largely encompassed within three discrete steps, each of about $2^{\circ}-3^{\circ} \mathrm{C}$ at $43 \mathrm{Ma}, 40 \mathrm{Ma}$ (middle/late Eocene), and $\sim 36 \mathrm{Ma}$ (earliest Oligocene). Benthic foraminiferal diversity decreased (Thomas, this volume). Changes in the calcareous nannofossil assemblages in the Maud Rise sequence reflect this cooling trend (Wei and Wise, this volume) so that even by the middle Eocene, the discoasters and sphenoliths, both warm-water groups, had become rare. Because of this, the middle Eocene calcareous nannofossil assemblages had become noticeably lower in diversity. In the tropics and subtropics, the sphenoliths were rapidly evolving and diversifying but were precluded from the Antarctic region because of the cooling trend. Hence, biostratigraphic correlations are made more difficult between the Antarctic and low latitudes. Nevertheless, the diversity of the Eocene calcareous planktonic assemblages on Maud Rise is moderately high, and assemblages have a temperate climatic character (Barker, Kennett, et al., 1988a).

To the north, on the Falkland Plateau, higher diversity middle Eocene calcareous nannofossil assemblages contain both discoasters and sphenoliths (Wise et al., 1985). This indicates that by the middle Eocene, a clear thermal gradient and biogeographic discontinuity had developed between Maud Rise and the Falkland Plateau. The cooling of Antarctica was beginning to strengthen the Earth's meridional thermal gradient.

Changes in isotopic gradients between various foraminiferal taxa (Figs. 5 and 6) suggest that the Eocene cooling trend was associated with an inferred decrease in the strength and/or duration of the seasonal thermocline and a reduction in seasonality expressed in the Antarctic surface waters (Stott et al., this volume). Decreased seasonality can be expected to result from the cooling of high-latitude surface waters. Evidence for this trend is best shown by decreases in the $\delta^{13} \mathrm{C}$ gradient between inferred shallow- and deep-dwelling planktonic foraminifers (Fig. 6 ), with an initial step at $\sim 47 \mathrm{Ma}$ (middle middle Eocene) and 
at $\sim 42 \mathrm{Ma}$. A relatively diverse dinocyst assemblage in the middle to upper Eocene at Site 696 suggests temperate or warmer conditions in the northern Antarctic Peninsula area. The diversity of this group decreased during the latest Eocene, probably in response to cooling (Mohr, this volume, chapter 36). A decrease in diversity in the planktonic foraminifers also occurred during the late middle Eocene to late Eocene as a result of the extinction of several forms (Stott and Kennett, this volume, chapter 34); late Eocene assemblages are dominated by only three or four species.

For post-Paleocene times, benthic foraminiferal assemblages on Maud Rise exhibit the highest diversity during the early middle Eocene (52-46 Ma) (Thomas, this volume). Subsequently, throughout the middle Eocene to earliest Oligocene, they exhibit well-known extinctions and originations (for references, see Thomas, this volume), the changes occurring in conjunction with decreases in isotopic temperatures (e.g., Shackleton and Kennett, 1975; Stott et al., this volume; Kennett and Stott, this volume).

Relatively warm climatic conditions for the middle and late Eocene of the Antarctic continent are indicated by both clay mineralogical and paleobotanical evidence. Middle and late Eocene clay assemblages, both on Maud Rise and the South Orkney microcontinent, continue to be dominated by smectite, indicating warm temperatures, seasonality in rainfall, and a predominance of chemical over physical weathering (Robert and Maillot, this volume).

A late middle to late Eocene in situ palynoflora (Site 696) in the South Orkney region is dominated by Nothofagus (southern beech) pollen and other groups that indicate the presence of a Nothofagus/conifer forest with an admixture of Proteaceae and an understory of ferns (Pteridophyta) (Mohr, this volume, chapter 36). Forests of this kind were likely to be associated with high rainfall $(1000-2000 \mathrm{~mm} / \mathrm{yr}$, or higher; Case, 1988), and the growth of ferns would have required seasonal frost-free conditions. The forest flora in the middle late Eocene was judged by Mohr (this volume, chapter 29) to be most likely warm temperate. Eocene floras that are similar, although dominated even more by Nothofagus, have been reported for the Antarctic Peninsula area, specifically King George Island (Stuchlik, 1981; Birkenmajer and Zastawnick, 1989) and Seymour Island (for references, see Mohr, this volume, chapter 29). These forests have been judged by Case (1988) to be of cool temperate character and to support previous interpretations of Eocene cool temperate conditions based on marine fossil sequences (Zinsmeister, 1982; Woodburne and Zinsmeister, 1984). Reworked Nothofagus assemblages have been documented in Eocene sediments adjacent to East Antarctica (Cranwell et al., 1960; Kemp, 1975; Truswell, 1983), indicating that such temperate forests were probably widespread throughout Antarctica during the Eocene. Case (1988) has proposed that an Antarctic biogeographic province dominated by Nothofagus (the Weddellian Province) represents continuous coastal, cool temperate conditions throughout the South Pacific and South Atlantic sectors during the Late Cretaceous and early Tertiary. He also suggested that large average leaf sizes of the middle Eocene floras perhaps indicate warmer conditions than during the Paleocene and late Eocene, which contain floras with smaller leaves.

\section{Late Eocene: Further Cooling}

Average sea-surface temperatures in the Weddell Sea continued to decrease during the late Eocene but seem to have never been lower than $8^{\circ}-10^{\circ} \mathrm{C}$ (Fig. 5). Such temperatures would imply an absence of coastal sea-ice (Stott et al., this volume; Kennett and Stott, this volume). Evidence for further cooling during the late Eocene includes the first appearance of diatomaceous sediments, although calcareous sediments continued to dominate throughout. This suggests a mild increase in upwelling rates, perhaps resulting from increased vigor of atmospheric circulation and leading to higher biosiliceous productivity. Calcareous nannofossils remained dominant, while planktonic foraminifers were reduced in importance. Cool waters continued to expand toward the north, as reflected by the presence of cooler calcareous nannofossil assemblages on the Falkland Plateau area (Wise et al., 1985). Nevertheless, several lines of evidence resulting from Leg 113 investigations suggest the continuation, during the Eocene, of temperate climatic conditions in the Antarctic. Such evidence includes the occurrence during the late Eocene of several species of Bolboforma, a calcareous planktonic group that apparently was restricted to temperate water masses throughout its evolution (see Kennett and Kennett, this volume, for references). The disappearance of all but one of these species in the Antarctic Paleogene occurred during the latest Eocene in response to cooling of surface waters. The final Paleogene disappearance of Bolboforma in Antarctic waters was soon after, during the earliest Oligocene. This perhaps reflects cessation of temperate conditions on Maud Rise and replacement by subpolar conditions (Kennett and Kennett, this volume). Comparison with other regions also suggests that, during the late Eocene, the Earth was still characterized by warm, equable climates with relatively low pole-to-equator temperature gradients (Kennett, 1977; Wolfe, 1978; Frakes, 1979; Brass et al., 1982).

Cooler continental conditions are indicated by a slight increase in illite relative to smectite (Robert and Maillot, this volume), suggesting a reduction in continental chemical weathering. The reappearance of kaolinite in low abundance is due to the erosion of prior-weathered terrains on the continent (Robert and Maillot, this volume).

\section{Paleogene Deep Water Formation: High or Low Latitude?}

A major question concerning the Paleogene Ocean, when the polar areas were much warmer than the present day, is the relative importance of deep and intermediate waters formed at high compared with lower latitudes. Leg 113 data have provided indirect evidence that, at least at times during the Paleogene, deep waters of the world ocean were derived predominantly from low latitudes. Deep waters were not necessarily always formed at high latitudes, including the Antarctic. However, the data are limited and the details are poorly known. Paleogene oxygen isotopic and benthic foraminiferal data have been presented as evidence for the presence, at intermediate water depths in the Weddell Sea, of warm saline waters produced outside the Antarctic (Kennett and Stott, this volume; Stott et al., this volume; Stott and Kennett, unpubl. data; Thomas, this volume). These data suggest that important multiple, possibly fluctuating, sources of oceanic deep waters were typical of the Paleogene Ocean and that, at least at times, there was a dominant component formed in middle to low latitudes. The oxygen isotopic evidence is addressed first.

Comparison of the Paleogene oxygen isotopic records between the two Maud Rise sites (Sites 689 and 690) shows that the oxygen isotopic gradient was inverted relative to the present day at certain periods during the Paleogene (Kennett and Stott, this volume). The $\delta^{18} \mathrm{O}$ values are lower for intermediate waters at the deeper Site 690 (Eocene depth $\sim 2250 \mathrm{~m}$; present-day depth $2914 \mathrm{~m}$ ), suggesting that temperatures were warmer by $\sim 2^{\circ} \mathrm{C}$ than at the shallower depths represented by Hole $689 \mathrm{~B}$ (Eocene depth $\sim 1400 \mathrm{~m}$; present-day depth $2080 \mathrm{~m}$ ). The presence of hiatuses in the cores limits the intervals of time for which such comparisons can be made. However, the reversed oxygen isotopic gradient was well developed at least by $46 \mathrm{Ma}$ (middle middle Eocene) and existed for much of the remaining Paleogene (Fig. 7). The reversed isotopic gradient was especially 
strengthened during the early Oligocene and seems to have reverted to a normal vertical isotopic gradient by $\sim 28 \mathrm{Ma}$ in the late Oligocene (Fig. 7). The inversion in the oxygen isotopic vertical gradient is not considered to have resulted from differential diagenesis between the two sites, or other potentially complicating factors (Kennett and Stott, this volume). Further isotopic evidence for an inversion in intermediate water temperatures is a progressive decrease and eventual reversal during the Eocene of $\delta^{18} \mathrm{O}$ values in planktonic relative to benthic values in the deeper Hole 690B, but not in Hole 689B (Stott and Kennett, this volume, chapter 34).

In the late Eocene, $\delta^{18} \mathrm{O}$ values of the measured planktonic foraminifers (subbotinids) are lower than the measured benthic foraminifers Cibicidoides). Warmer deep waters of the Paleogene are inferred to have been produced at middle to low latitudes, probably in the Tethys region, which then contained extensive shallow-water platforms (e.g., Dercourt et al., 1986), ideal sites for the formation of high-salinity water through evaporative processes, although other potential source regions are possible. Furthermore, the Paleogene was a time of relatively high sea level compared with the Neogene (Vail and Hardenbol, 1979; Haq et al., 1987), leading to greater flooding of the continental margins and hence contributing to the formation of evaporative basins.

The occurrence of warm, saline deep waters in the geologic past was anticipated by Chamberlin in 1906 and later considered to be feasible in modeling experiments carried out by Brass et al. (1982). These conclusions were based upon the assumption that, at some time in the past, the polar regions (including the Weddell Sea) may have been too warm to provide a major source of cold, deep waters to the ocean basins. This includes the Weddell Sea region, the present-day seat of production of cold oceanic bottom waters. Another major process that may have contributed to a reduction in the production of cool, dense waters from the Antarctic was a potential reduction in surface-water salinities in Antarctic coastal areas. It is possible that for much of the Paleogene, there occurred higher precipitation and freshwater runoff from the Antarctic continent. This probably peaked at the Paleocene/Eocene boundary based on the abundance of kaolinite at that time (Robert and Maillot, this volume). The occurrence of widespread Nothofagus forests in coastal areas, as discussed earlier, supports this hypothesis. Case (1988) noted that these forests, in the present day, are associated with high annual rainfall (1000-3000 mm). Furthermore, Barrett et al., (1989), provided sedimentological evidence for important early Oligocene freshwater runoff into the Ross Sea. Such high rainfall in the Paleogene would have reduced surface-water salinities in the coastal and embayment areas of Antarctica, including the Weddell Sea and Ross Sea areas. These areas are especially important modern sources of Antarctic Bottom Water formation.

Woodruff and Savin (1989) proposed that warm, saline waters derived from the Tethys region continued to influence the oceans as late as the early Miocene. They suggested that the closure of the Tethys that took place near the end of the early Miocene resulted in major reduction in the production of warm, saline deep waters. These changes, they suggested, were a major factor in the development of a large, permanent ice-sheet on East Antarctica during the middle Miocene $(\sim 15 \mathrm{Ma})$.

The other, but distinctly different, line of evidence in support of low-latitude sources of deep waters to the Weddell Sea, at least at times during the Paleogene, are the characteristics of Paleogene benthic foraminiferal assemblages on Maud Rise (Thomas, this volume). Thomas has interpreted changes in assemblages with respect to change in the degree of oxygenation of deep waters. This evidence provides a somewhat different picture of the history of low-latitude influences on deep waters to the Weddell Sea. This evidence suggests that during the Paleo- gene there was no single transition from deep waters formed in low latitudes to those formed at high latitudes. Instead, characteristics of the benthic foraminiferal assemblages have suggested to Thomas (this volume) that deep to intermediate waters of Maud Rise were well-oxygenated during the Maestrichtian through early Paleocene and during the latest Eocene through the Neogene, suggesting a high latitude source of lower bathyal waters. They were less well ventilated during the Paleocene and middle to early late Eocene, and least ventilated during the latest Paleocene through earliest Eocene, suggesting low-latitude sources.

Kennett and Stott (this volume) suggested that there were two significantly different oceans during the Paleogene, each consisting of different deep-water structure. Proteus, of Eocene and Paleocene age, was a two-layered thermospheric ocean, consisting of warmer, saline deep waters possibly formed at middle to low latitudes and overlain by cooler intermediate waters formed at high latitudes. Proto-oceanus, of early to middle Oligocene age, was a three-layered ocean consisting of cold, dense bottom waters formed in the Antarctic (proto-AABW), overlain by warm, saline deep waters and, in turn, overlain by cool intermediate waters formed in the polar regions. This represents an ocean that combined both halothermal and thermohaline processes, and was Oceanus, the predecessor of the modern thermohaline ocean in which the formation of the deepest waters is dominated by high-latitude processes. The suggested models of deepwater circulation using the oxygen isotopic record are clearly oversimplistic and generalized but have been presented as a base for further investigations. Even during the Oligocene when this oxygen isotopic gradient is most clearly inverted, there were times when this gradient disappeared (Fig. 7; Kennett and Stott, this volume). These suggested trends are speculative until recognized in other parts of the oceans.

\section{Eocene/Oligocene Boundary Event}

The Eocene/Oligocene boundary is associated with changes in a number of biotic and abiotic elements in the Weddell Sea sequences and in adjacent continental areas. These changes clearly record the transition from the relatively warm conditions of the late Eocene to distinctly cooler conditions of the Oligocene. At Site 689, the terminal Eocene event is marked, in part, by a rapid, distinct positive shift in $\delta^{18} \mathrm{O}$ of between $1.0 \%$ and $1.5 \%$ in both benthic and planktonic foraminifers in the earliest Oligocene ( $\sim 36 \mathrm{Ma})$ (Kennett and Stott, this volume; Stott et al., this volume). This oxygen isotopic shift, reported by many workers from throughout the world's ocean basins (Shackleton and Kennett, 1975; Kennett and Shackleton, 1976; Murphy and Kennett, 1986; Oberhänsli and Tourmarkine, 1985; Miller and Fairbanks, 1985) is isochronous according to magnetobiostratigraphic calibration. Most workers consider the isotopic shift to represent a climatic threshold in Antarctica resulting in the onset of freezing of Antarctic surface waters near Antarctica, and hence the cooling of oceanic deep waters derived from Antarctica and/or the beginning of accumulation of continental ice (for references, see Kennett and Stott, this volume). The isotopic shift in the earliest Oligocene was twice that of the previous two steps that occurred during the Eocene. Thus the shift represents an Antarctic climatic change of great significance. Because of the possibility that ice accumulation commenced on the continent at this time, it is difficult to estimate the extent of Antarctic surface-water cooling, although this was probably no more than $\sim 4^{\circ} \mathrm{C}$ (Stott et al., this volume).

The isotopic shift may also record the beginning of important thermohaline circulation in the ocean basins (Shackleton and Kennett, 1975; Kennett and Shackleton, 1976) and perhaps the initiation of the psychrosphere (Benson, 1975; Kennett and Shackleton, 1976; Benson et al., 1984). On Maud Rise, this interval is marked by a distinct increase in dissolution of the cal- 
careous microfossils. The inversion in the oxygen isotopic gradient recorded in the Maud Rise sequence strengthened during the early Oligocene. This has been interpreted to reflect large changes in the character of oceanic circulation (Kennett and Stott, this volume). In spite of this, the benthic foraminifer assemblages exhibit only relatively minor extinctions during the terminal Eocene event (see Thomas, this volume, for references). The benthic foraminifer assemblages of Maud Rise, or elsewhere, exhibit no sudden or brief extinction event associated with the inferred change in deep oceanic circulation at this time (Thomas, this volume). Instead, the benthic foraminifers changed both gradually and in discrete steps over an extended interval ranging from the late middle to the late Eocene (Thomas, this volume).

There is also evidence of a record of increased vigor of deepwater circulation during the terminal Eocene event in the Weddell Sea. This includes a major hiatus of Lower Cretaceous to middle lower Oligocene age at Site 693 (Dronning Maud Land), and a hiatus of late Eocene-early Oligocene age at Site 690 (Maud Rise). These unconformities were evidently formed by erosion of deep-sea sediments. The Eocene/Oligocene boundary is associated with widespread hiatus formation in the deep sea basins (see Barker, Kennett, et al., 1988a, for references). As at Site 693, many of these hiatuses are erosional, so the causal intensification of bottom currents cannot always be identified precisely with this particular event. Nevertheless, a high-latitude origin is indicated, and the period of the hiatus often includes the Eocene/Oligocene boundary. The initiation of a basal thermohaline circulation at this time is compatible with a lack of major modification of the benthic environment at the Maud Rise sites, since these would have been at intermediate depths at the time, and may have remained within the older water masses.

Coeval with the oxygen isotopic shift was a major and rapid change in the composition of clays derived from East Antarctica and deposited on Maud Rise. The smectite-dominated assemblages, typical of the Late Cretaceous to late Eocene and considered to reflect warm continental conditions, were replaced by clays dominated by illite with additional chlorite and irregular mixed layers (Robert and Maillot, this volume). This change in clay mineralogy was in response to the climatic cooling and cryospheric development of East Antarctica at that time. It is inferred that the climatic change created a strong decrease in chemical weathering and soil development and increased erosion of parent rocks. Weak hydrolysis prevents the formation of smectite as only moderate alteration of parent rocks is possible (Robert and Maillot, this volume). These climatically-induced clay mineralogical changes apparently did not extend northward to the Antarctic Peninsula area, judging from the sequence at Site 696 . In this sequence, smectite remained the dominant clay mineral during the Oligocene, suggesting that the Antarctic Peninsula area, the assumed principal source, remained relatively warm. Alternatively, the smectite-dominated clays may have been partly transported by ocean currents from warmer areas to the north (Robert and Maillot, this volume).

\section{Oligocene Climatic and Oceanographic Conditions}

A wide range of parameters indicates that climate remained cool throughout the Oligocene and at no time returned to the warmer conditions that marked the Eocene. Because of the potential complication of continental ice accumulation, at least at times during the Oligocene, it is difficult to estimate isotopic paleotemperatures with much certainty. Nevertheless, minimum surface-water temperature suggested by the isotopic composition of the subbotinids was close to $0^{\circ} \mathrm{C}$. At times, temperatures increased above this minimum during the Oligocene, such as an increase of $\sim 5^{\circ} \mathrm{C}$ near $33 \mathrm{Ma}$ (Stott et al., this volume).

Decreases in the diversity of planktonic foraminiferal (average from $\sim 5$ to 2-3 species) (Stott and Kennett, this volume, chapter 34) and calcareous nannofossil assemblages (from $\sim 9$ 12 to $3-8$ species) (Wei and Wise, this volume) mark the early Oligocene relative to the late Eocene, the change occurring over the boundary. Planktonic foraminiferal assemblages of Oligocene age present a subpolar rather than a polar aspect. Further changes in the biota during the Oligocene record further cooling. The middle Oligocene was marked by a further decrease in planktonic foraminiferal diversity, as previously recognized in Subantarctic Pacific sequences (Jenkins, 1975). The relative abundance and the quality of preservation are further reduced during the Oligocene as the calcareous microfossil groups were progressively replaced by the siliceous groups. On Maud Rise, by the late Oligocene, dissolution had noticeably increased in both planktonic and benthic foraminifers, as intermediate waters became more corrosive. Although sediments continued to be dominated by calcareous nannofossil ooze, a marked increase in biogenic silica deposition (diatoms and radiolarians) is inferred to have resulted from increased upwelling in the Antarctic region (Barker, Kennett, et al., 1988a). The first dominantly biogenic siliceous (diatomaceous) sediments were deposited during the latest Oligocene, reflecting further strengthening of upwelling in the Antarctic region. Early Oligocene surface water coolness is reflected by very low dinoflagellate diversity (two species) in the Dronning Maud Land margin sequence (Site 693), comparable to the diversity of modern Antarctic floras (Mohr, this volume, chapter 36). No dinoflagellates were recorded in the late Oligocene. Due to the early Oligocene cooling, calcareous nannofossil assemblages typical of the Antarctic (Weddell Sea) expanded northward over the Falkland Plateau, effectively eliminating the discoasters from that area (Wei and Wise, this volume). As a result, both regions exhibit remarkably similar calcareous nannofossil assemblages during the Oligocene. The diversity of calcareous nannofossil assemblages continued to decline, as a result of successive extinctions, reaching very low diversity assemblages and then eventually a complete absence during the Miocene. Even within the Weddell Sea itself, the abundances and diversity of Oligocene calcareous nannofossils decrease from Maud Rise (Sites 689 and 690) toward the southern and northwest margins (Sites 693 and 696). This gradient reflects a shallowing of the calcium carbonate compensation depth toward the continent and perhaps also the presence of a cool, coastal current and seaice influencing planktonic assemblages near to the Weddell Sea's continental margins (Wei and Wise, this volume). This contrast persists to the present day, at least in the abundance of icebergs and the extent of seasonal sea-ice cover. The CCD was elevated near the margins, perhaps because of cooler temperatures in areas of bottom water formation, lower calcareous biogenic productivity, and seasonal sea-ice formation in the near-continental areas. Changes in the benthic foraminifer assemblages on the South Orkney microcontinent (Site 696) occur between the middle late Eocene and an overlying, poorly dated sequence generally dated as Oligocene to early Miocene. At this time, the replacement of dominantly calcareous by agglutinated assemblages marks a fundamental change to waters highly undersaturated in calcium carbonate even at the shallow $(<\sim 600 \mathrm{~m})$ paleodepths of Site 696 . It is likely that this change occurred near the Eocene/Oligocene boundary and supports the contention of fundamental changes toward the production of deep, cold bottom water from the Antarctic continental margin (Barker, Kennett, et al., 1988a; Kennett and Stott, this volume). An increase in upwelling of more nutrient-rich intermediate waters in the Antarctic area during the Oligocene, as inferred from slight increases $(\sim 10 \%-20 \%$ of smear-slide components; Barker, Kennett, et al., 1988a) in siliceous microfossils, may have brought more saline waters to the surface near the continent. This may, in turn, have contributed to higher densities required to produce the cold, dense bottom waters from Antarctica that by then had 
a major influence on the global ocean (Kennett and Stott, this volume). This process is similar to that which produces North Atlantic Deep Water by cooling, in the modern northernmost Atlantic, of relatively saline waters originally produced in the Mediterranean Sea.

The present Antarctic Circumpolar Current (ACC) and associated Polar Front isolate Antarctica within a ring of cold water: the ACC developed as Drake Passage opened and the Scotia Sea developed, to create a complete deep-water pathway around Antarctica, probably during the early Miocene (Barker and Burrell, 1982). To the south of the modern Polar Front, surface-watertemperature variation is small, and across the Front it is large. During the Oligocene, calcareous nannofossils were comparable on Maud Rise and the Falkland Plateau, and showed higher diversity than those from near the Antarctic Peninsula and Dronning Maud Land margin. This suggests an absence of any strong zonal isolating feature like the present $\mathrm{ACC}$, but the presence of a temperature gradient between Maud Rise and areas south and west. This implies a clockwise circulation in the Weddell Sea, and sea-ice formation near the continent. Similarly, the CCD was abnormally shallow at the Antarctic Peninsula and Dronning Maud Land margins throughout the Oligocene record, but not at Maud Rise until the Miocene, and even then not consistently so, suggesting that the major modification of surface and intermediate water masses during the Oligocene was taking place in the southern Weddell Sea rather than at a Polar Front. The only contrary climatic indication comes from the clay mineralogy that indicates warmer conditions for the Antarctic Peninsula compared with Maud Rise. However, the clay mineralogy more likely reflects climatic conditions of the adjacent land masses rather than the circulating water masses: consistently, West Antarctica (particularly the Antarctic Peninsula) has lagged behind East Antarctica in the intensity of its glaciation, and the terrigenous clays at Maud Rise reflect climatic conditions on East Antarctica, the nearest continental source. Thus, the Oligocene sediments at Leg 113 sites show no indication of the presence of the ACC or Polar Front, but they do indicate a clockwise Weddell gyre and the influence of sea-ice formation at the Antarctic margin.

That Weddell Sea surface waters were close to freezing during the Oligocene is supported by the first observed ice-rafted sediments in the Leg 113 sequences (Barker, Kennett, et al., 1988a). However, this material is rare to uncommon or still of unproven ice-rafted origin in all the recovered sequences of Oligocene or probable Oligocene age. At Maud Rise, it consists of very rare dropstones of late Oligocene age. Rare terrigenous fine-grained sand particles (Kennett, unpubl. data) may either be ice-rafted or wind blown to the region. Close to the East Antarctic margin (Site 693, $\sim 140 \mathrm{~km}$ north of Dronning Maud Land), coarse sediments are relatively common, but it remains unclear if this represents IRD or if the material was transported in slumps from shallow water. Many of the pebbles are weathered, suggesting that the superficial deposits of a pre-glacial terrain were being eroded. Evidence for cryogenic conditions during the Oligocene will be discussed in the next section. The presence of benthic diatoms in the Oligocene at Site 693 suggests areas of shallow (maximum $50 \mathrm{~m}$ ) water depth lacking permanent shelf-ice cover on the continental margin. This compares with the deep ice-covered Antarctic shelf of the present day (Barker, Kennett, et al., 1988a).

Although cryospheric development had clearly commenced on East Antarctica at the beginning of the Oligocene (Kennett, 1977; Barrett et al., 1987), a significant body of information shows that forests dominated by Nothofagus existed in at least some coastal areas of East Antarctica and on the Antarctic Peninsula during the early Oligocene. Previous work has shown that major plant extinctions took place in the Antarctic at the end of the Eocene, apparently as a result of major climatic cooling (Kemp, 1975; Kemp and Barrett, 1975; Truswell, 1983). The question has remained, however, as to whether forests survived in any areas. Mohr (this volume, chapter 36) reports evidence for a very low diversity palynoflora of early Oligocene age in the Site 693 sequence off East Antarctica (Dronning Maud Land). The input of land-derived organic matter from higher plants seems to have ceased by the late early Oligocene in this area. Mohr suggested, from this evidence, that higher plant growth (megaflora) on the Antarctic continent south of the Antarctic Peninsula ceased at some time during the early Oligocene. Sediments of possible Oligocene age (Site 696) were probably deposited in highly oxygenated environments and hence are not suitable for the preservation of palynomorphs. However, the presence of rare, reworked freshwater diatoms in these sediments indicates that freshwater lakes occurred on the Antarctic Peninsula at this time (Barker, Kennett, et al., 1988a). Furthermore, sequences as young as the late Oligocene exhibit fossil megafloras dominated by Nothofagus in the northern Antarctic Peninsula region (e.g., Stuchlik, 1981; Zastawniak et al., 1985). These have been interpreted to be indicative of cool to warm temperate rain forests (Zastawniak et al., 1985). In the Ross Sea area adjacent to East Antarctica, in situ palynomorphs of Oligocene age in the CIROS-I sequence are considered to represent evidence of a diverse forest flora in humid-temperate to perhaps warm-temperate climates with a limited temperature range (Mildenhall, 1987). The fossils are preserved in a sequence that otherwise reflects highly fluctuating climatic conditions including extensive cryospheric development, but their presence suggests that such forests persisted during the early Oligocene and perhaps, in this area, into the late Oligocene.

\section{Oligocene Cryospheric Development: East Antarctica}

It is very clear and widely accepted that the cryospheric development of East Antarctica was well established in the Oligocene (for references, see Kennett, 1977, 1978). However, a major question that has remained is the extent and volume of ice accumulation on East Antarctica during the Oligocene to early Miocene. Shackleton and Kennett (1975) and Kennett (1977) recognized that the Antarctic continent was significantly "glaciated" during the Oligocene. However, they interpreted the deep-sea oxygen isotopic record for the Oligocene in terms of Antarctic climatic cooling and sea-ice development rather than the accumulation of ice-sheets on the continent. Subsequently, more detailed studies have suggested that there were periods of ice-growth at times during the early, middle, and late Oligocene (e.g., Keigwin and Keller, 1984; Miller and Thomas, 1985; Miller et al., 1987a). Nevertheless, data are limited and the dating of large ice-sheets on Antarctica and their effect on global climatic evolution has remained controversial. There are several elements involving ice accumulation that make up the global cryosphere (Fig. 8). These range from alpine glaciers to major land-based ice-sheets and also include sea-ice, which can be perennial or seasonal. In the evolutionary progression of an expanding cryosphere on a continent such as Antarctica, it is likely that ice accumulated in succession, as shown in Fig. 8. Much previous work has not attempted to differentiate the evolutionary state of the Antarctic cryosphere; instead, the general term "glaciation" has often been employed. However, the term "glaciation" incorporates any or all of the various elements that can make up the cryosphere (Fig. 8), and thus is of limited use. It is important, instead, to attempt to separately identify the presence of each of these elements in the geologic record. This will, in turn, better assist in the understanding of the evolution of the cryosphere and of global climate.

What do the results from Leg 113 indicate about cryospheric evolution during the Oligocene? The distribution and abundance 


\section{Cryospheric Terms}

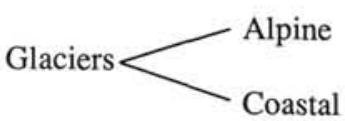

Small ice-sheets

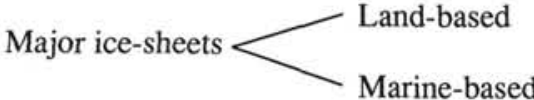

Ice-shelves

Sea-ice (extensive)

Figure 8. Different elements involving ice accumulation that make up the global cryosphere and expected evolutionary progression toward a major polar cryosphere, as in modern Antarctic.

of ice-rafted detritus do provide a general guide to the intensity of ice-growth, especially when compared with the distribution of such materials in overlying Neogene sediments.

Only very rare dropstones (perhaps in situ in Hole 689B) were observed in the Oligocene of the Maud Rise sequence, these occurring in the late Oligocene. Rare particles of terrigenous fine sand occur, but these are no more abundant than during the Eocene (J. Kennett, unpubl. data). It is unclear how this sand was transported to Maud Rise, but it is not inconceivable that it was wind-blown (Betzer et al., 1988). Ice-rafted detritus ( $>63 \mu \mathrm{m}$ sand-sized fraction), in the Maud Rise sequence, increased in abundance during the late Miocene and became abundant in the sand-sized fraction by the Pliocene (Fig. 9). The deposition of abundant fine, well-sorted glauconite sand in the early Oligocene of Site 693 need not necessarily have resulted from Antarctic ice-sheet development as suggested by Grobe et al. (this volume). However, a noticeable upward decrease in the

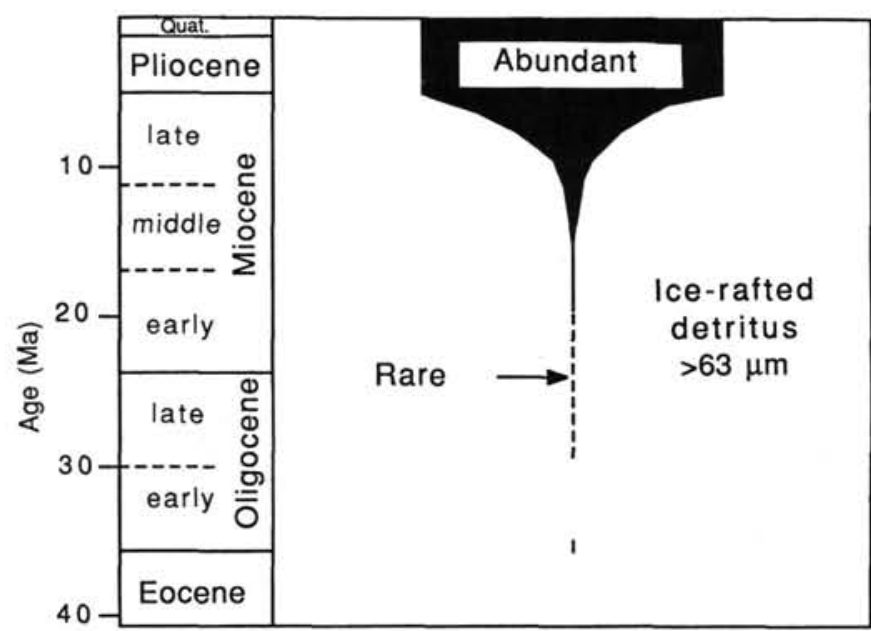

Figure 9. Generalized diagram showing relative abundance of ice-rafted detritus ( $>63 \mu \mathrm{m})$ in Hole 690B (Maud Rise). sorting of sand-sized terrigenous sediments during the late Miocene in Site 693 perhaps reflects an increase in the importance of the ice-rafted component.

In the South Orkney area (Site 696), there is little evidence for cryospheric activity in the poorly dated sequence that is of possible Oligocene to early Miocene age. Ice-rafted detritus is absent except for a few small dropstones (Barker, Kennett, et al., 1988a). A clay mineral association of abundant to exclusive smectite and common to abundant illite indicates that climate on the northern Antarctic Peninsula was, at times, warm and humid enough to form smectite and yet, in comparison with the underlying Eocene, had become cool enough to form clays as a result of physical weathering (Robert and Maillot, this volume). It is also possible that the clays were, in part, transported to the South Orkney microcontinent by southward-flowing surface currents from South America.

In summary, the distribution and abundance of ice-rafted detritus are very limited in Oligocene sequences drilled during Leg 113. Detailed quantitative studies of the nonbiogenic coarser sedimentary fractions are still required. The available data, per se, suggest rather limited development of the cryosphere compared with that of the late Neogene. Overall, the Leg 113 data do not support the hypothesis of major Antarctic ice-sheets of Oligocene age. However, this absence of convincing evidence does not necessarily mean that ice-sheets were absent at times during the Oligocene. Zachos et al. (1989), for instance, present compelling evidence for a brief interval of major Antarctic ice growth during the earliest Oligocene. This conclusion is based on an observed association at Site 748 on the central Kerguelen Plateau (latitude $\sim 58^{\circ} 26^{\prime} \mathrm{S}$ ) of a $30-\mathrm{cm}$ interval containing in situ traces of ice-rafted detritus with the positive oxygen isotopic shift that marks the earliest Oligocene. The presence of ice-rafted detritus at such a low latitude on the Kerguelen Plateau could only result from transport via large icebergs derived from an extensive ice-sheet (Schlich, Wise, et al., 1989). Also of significance is a possible lack of ice-rafted detritus during the remainder of the Oligocene and the early Miocene on the Kerguelen Plateau. The Maud Rise sequence, at a similar latitude, contains no clear evidence during the Eocene/Oligocene transition of ice-rafted detritus. This perhaps reflects diachronism of major ice growth on East Antarctica or an isolation from iceberg tracks.

A thick sequence of glacial diamictites of Oligocene age was drilled at Prydz Bay on the East Antarctic margin in the southern Indian Ocean during Leg 119 (Shipboard Scientific Party, Leg 119, 1988). The significance of these deposits with respect to the extent of the cryosphere is still being evaluated, but preliminary interpretations (e.g., Shipboard Scientific Party, Leg 119,1988 ) have stated that they represent evidence for "fullscale" ice-sheet development on East Antarctica during the Oligocene, which is not supported by Leg 113 data. The presence of glacial diamictites on a polar continental margin does not necessarily, by itself, represent evidence of continental ice-sheets. For example, glacial diamictites within the upper Miocene Yukataga Formation on the southern coast of Alaska were not deposited at the edge of continental ice-sheets (Lagoe, 1983) but at the margins of glaciers and from icebergs calving from glacial fronts of mountain and valley glaciers. There is no evidence for ice-sheets of any size on Alaska during the late Neogene.

Likewise, Oligocene glacial diamictites (Barrett et al., 1989) in the CIROS-I sequence on the continental margin of Victoria Land, in the Ross Sea $\left(\sim 77^{\circ} \mathrm{S}\right)$ also do not, by themselves, necessarily indicate deposition from continental ice-sheets. The lower part of the sequence (lower Oligocene; $36-36.5 \mathrm{Ma}$ ) is largely represented by prodelta mudstones containing ice-rafted dropstones. The upper part of the sequence (Upper Oligocene-lower Miocene; $30.5-22 \mathrm{Ma}$ ) is dominated by diamictites alternating 
with sand and mud. Barrett et al. (1989) have interpreted the sequence as evidence for a temperate (not polar) glacial regime; for glaciers that were wet-based, and that muddy sediments were carried by meltwater streams into the ocean. Glaciers were calving at sea level for much of the time. Paleobotanical evidence from the sequence indicates an association of temperate forests in humid climates (Mildenhall, 1987). During the coldest Oligocene episodes, temperatures were inferred to have been much higher than the present day. Barrett et al. (1989) recognized that the extent of ice accumulation is difficult to estimate but suggested the presence of ice-sheets of great size, extent, and longevity, such as during the Northern Hemisphere Quaternary. This conclusion was based not so much on the evaluations of the environment of deposition during the Oligocene at the CIROS-I site, but on the presence of coeval glacial diamictites in Prydz Bay on the opposite side of the continent, and on the results of modeling experiments by Robin (1988). We believe that the bulk of the CIROS-I evidence favors the existence of highly variable climates and extensive temperate glaciation without major ice-sheets at least during the early Oligocene, although recognizing that ice-sheets may have developed during short intervals, such as during the earliest Oligocene. The continent was much warmer than today, but heavily glaciated in parts; somewhat similar to Alaska in the present day.

By the Oligocene, biogenic calcium carbonate essentially ceased being deposited on both the east and west Antarctic margins of the Weddell Sea (Sites 693, Dronning Maud Land; 696, South Orkney microcontinent). An absence of calcium carbonate in the Oligocene of Site 696 indicates that the CCD remained very shallow on the continental margins of Antarctica during this interval, remaining above the present-day depth of $650 \mathrm{~m}$, and considerably shallower than at Maud Rise during the Oligocene and Neogene. The shallowness of the CCD throughout almost the entire Oligocene and Neogene on the Weddell Sea margins and elsewhere around Antarctica (Kennett, 1966; Echols, 1971; Hayes, Frakes, et al., 1975) almost certainly resulted from the presence of highly corrosive bottom waters and the low productivity of calcareous microfossils. Thus, the oceanographic environment creating these characteristics became established in the Oligocene.

\section{Early Neogene: Increased Upwelling and Warm Episodes}

An important hiatus is present across the Oligocene/Miocene boundary on Maud Rise (Barker, Kennett, et al., 1988; Gersonde et al., this volume; Thomas et al., this volume) and is coeval with hiatuses on the Falkland Plateau (Wise, 1983) and the Kerguelen Plateau (Shipboard Scientific Party, 1988). The origin of widespread hiatuses in the Southern Ocean at this time (Wei and Wise, this volume) could be linked with intensification of deep-water flow resulting from the development of the Antarctic Circumpolar Current when the Drake Passage opened (Barker and Burrell, 1977, 1982). Hiatuses of this age, however, are widespread in the ocean basins (Keller et al., 1987) suggesting, instead, that the causes of intensified deep-sea circulation are related to a broader change such as high-latitude cooling, which, itself, may have developed as a result of Drake Passage opening.

Siliceous biogenic sediments began to dominate at times during the latest Oligocene-earliest Miocene, reflecting further developments in Antarctic surface waters. This marks a further step in the long-term trend toward increasing biosiliceous sedimentation during the Neogene. This trend is generally attributed to a progressive increase in Southern Ocean upwelling as a result of increased wind strength due, in turn, to Antarctic cooling (Kennett, 1977, 1978; Brewster, 1980; Grobe et al., this volume).
On Maud Rise during the earliest Miocene, planktonic foraminiferal assemblages became essentially monospecific providing a polar appearance, and there was a drastic reduction in calcareous nannofossil diversity (from about six to two species; Wei and Wise, this volume). Diatom and calcareous nannofossil oozes were deposited alternately during the early and middle Neogene until the middle late Miocene, thus representing a transition between the dominantly calcareous Paleogene-earliest $\mathrm{Ne}$ ogene and the dominantly biosiliceous late Neogene. These alternations are clearly reflected in the changes in relative calcium carbonate abundances (O'Connell, this volume, chapter 55) and may represent the repeated passage of an oceanographic front over Maud Rise or the intermittent existence of a front (Barker, Kennett, et al., 1988a). The occurrence of benthic diatoms of Oligocene to early Miocene age at Site 693 near East Antarctica indicates the presence of a shallow, partly ice-free continental shelf, although the presence of ice-rafted detritus indicates cryospheric activity on the continental margin of East Antarctica (Barker, Kennett, et al., 1988a).

During the late early Miocene, the calcareous nannofossils and planktonic foraminifers on Maud Rise exhibit a slight temporary increase in diversity, and the calcareous nannofossils exhibit sharp fluctuations in abundance. In the Bellingshausen Basin $\left(\sim 65^{\circ} \mathrm{S}\right)$, even the calcareous planktonic form Bolboforma reappeared for a brief interval during the late early Miocene (Rögl and Hochuli, 1976). Oxygen isotopic temperatures determined for sequences elsewhere, including the Subantarctic (Shackleton and Kennett, 1975; Kennett, 1986; Miller et al., 1987a) indicate that this was the climax of Neogene warmth.

Increased deposition of ice-rafted detritus occurred during the early Miocene of Site 693 near Dronning Maud Land, indicating an increase in iceberg activity. There may have been an increase in ice accumulation near the margins at that time resulting from higher precipitation associated with warmer conditions (Grobe et al., this volume). However, any ice accumulation during the early Miocene could not have been sufficiently large to affect the oceanic oxygen isotopic record, which exhibits relatively low $\delta^{18} \mathrm{O}$ values during this interval (e.g., Kennett, 1986).

While ice-rafted sediments at Southern Ocean sites are a clear indication of ice on or around the Antarctic continent, and a simultaneous increase in IRD at several widely distributed sites probably indicates intensified cryospheric development, there is no simple relationship between the abundance of IRD at a particular site and the intensity of glaciation (e.g., Drewry, 1986). For example, the basal load of a wet-based ice-sheet will largely be deposited close to the grounding line, perhaps before the icesheet has even calved. In contrast, sediment blown or washed onto pack-ice may be transported large distances, as may large rocks that fall onto the surface of valley glaciers from the surrounding elevated topography. IRD concentration may therefore reflect sea-ice distribution, surface melting and wind strength, the degree of dissection of topography, the type and degree of erosion, and sediment availability on the continent. Icebergs are melted mainly underwater, so the melting rate will depend partly on the temperature of surface waters along the iceberg path; a peak of IRD deposition at a site might reflect the proximity of an oceanic front, and changes in IRD concentration may result from changes in circulation unrelated to changes in the cryosphere.

\section{Middle Miocene: Major Cryospheric Development and West Antarctic Cooling}

The early middle Miocene is often regarded as a time of renewed cooling and of major expansion of the East Antarctic ice-sheet (e.g., Shackleton and Kennett, 1975; Savin et al., 1975). Other workers (e.g., Matthews and Poore, 1980) preferred to interpret the well-known major positive $\delta^{18} \mathrm{O}$ shift in 
the middle Miocene as a cooling of oceanic deep waters rather than the accumulation of Antarctic ice. Kennett (1986) argued that the earliest phase of the benthic oxygen isotopic shift (1614.6 Ma, corresponding to about 15-13.5 Ma of the time scale of Berggren et al., 1985b, c) resulted from a cooling of high-latitude deep waters, with the later phase (14.6-13.2 Ma) resulting from formation of an extensive ice-sheet on East Antarctica. This interval (14 Ma) also marks the beginning, during the Neogene, of a trend toward lower sea levels (Haq et al., 1987). A major hiatus $(\sim 16-9 \mathrm{Ma})$ at Site 693 may have been caused by an invigoration of bottom waters related to these changes in the Antarctic cryosphere (Barker, Kennett, et al., 1988a). Changes also occurred at this time in the benthic foraminiferal assemblages on Maud Rise (Thomas, this volume), these being coeval with benthic foraminiferal changes elsewhere in the ocean basins (see Thomas, this volume, for references). An interval between $\sim 15$ and $11.5 \mathrm{Ma}$ is barren of calcareous benthic foraminifers (Thomas, this volume) and is the result of associated intense calcium carbonate dissolution. These changes probably resulted from an increase in the vigor of deep-sea circulation during this interval of expanded Antarctic cryospheric development, as postulated by Shackleton and Kennett (1975) and Kennett (1977). Benthic foraminifers became rare or absent on Maud Rise following the middle Miocene (except for an interval between 11.5 and $9 \mathrm{Ma}$ ) and for the remainder of the Neogene, and exhibit much lower diversity (Thomas, this volume). During the middle to late Miocene, calcareous nannofossil and planktonic foraminiferal assemblages, when present, became essentially monospecific.

An increase in ice-rafted detritus and other sedimentological changes during the middle Miocene in the sites nearer to East Antarctica generally support the hypothesis of cooling and ice accumulation at that time (e.g., Kennett, 1977). On Maud Rise, a noticeable increase occurs in concentrations of sand-sized, icerafted detritus (Fig. 9), although this material did not become abundant there until the latest Miocene-early Pliocene (J. Kennett, unpubl. data). Furthermore, diatom-rich hemipelagic sediments that overlie the hiatus exhibit an upward increase in sedimentation rates. This resulted from increased supply of terrigenous sediments to the continental margin, perhaps because of increased ice growth, and also because of higher rates of diatom productivity and deposition. Sedimentary changes that occurred during this interval are reflected in downhole logs (Golovchenko and O'Connell, this volume). Lower upper Miocene sediments on the Dronning Maud Land margin are also marked by an increase in smectite content. This change either reflects an increase in the erosion of ancient sediments (from the continental margins) by the then-expanding ice-sheets and/or by bottom currents (Robert and Maillot, this volume).

The sequences closer to the East Antarctic Margin thus clearly show evidence of increased ice growth during the middle Miocene. This is not the case in the region adjacent to West Antarctica (Site 696), where there is a lack of ice-rafted detritus in the Neogene sequence until the late late Miocene (Barker, Kennett, et al., 1988a). Although this suggests an absence of major ice growth on West Antarctica, there is evidence from the northern Antarctic Peninsula of glacial development as early as the late Oligocene to earliest Miocene (Birkenmajer, 1987). Perhaps the absence of an early Neogene glacial-marine record in the area of the South Orkney microcontinent indicates that this reported terrestrial glacial event was quite limited or that the interval has not yet been observed in the marine record. Nevertheless, the Leg 113 data do suggest that a major cooling of the Antarctic Peninsula occurred during the middle Miocene. At this time, smectite, the dominant clay mineral in the early middle Miocene, was replaced by an assemblage dominated by illite and chlorite (Robert and Maillot, this volume). This indicates that the clays then originated from continental areas where weak hy- drolysis prevented the development of the soils and favored physical weathering and erosional processes. A similar change in clay associations occurred during the earliest Oligocene at sites adjacent to East Antarctica and Maud Rise, indicating that major cooling occurred earlier in East Antarctica compared with West Antarctica.

In the Weddell Abyssal Plain sequence (Site 694), displaced benthic and neritic planktonic diatoms contained within turbidites are particularity conspicuous during the middle Miocene and are also present during the early late Miocene. These turbidites were probably derived from the West Antarctic region (Barker, Kennett, et al., 1988a). The presence of these diatoms suggests an absence or near absence of ice cover over the shallow part of the West Antarctic continental shelf during the middle Miocene and early late Miocene. These observations indirectly indicate an absence of a major West Antarctic ice-sheet during this time. Such an interpretation is in accord with the interpretations of Ciesielski et al. (1982) for the development of the West Antarctic ice-sheet no earlier than the late Miocene. This is further supported by the occurrence of displaced freshwater diatoms characteristic of lakes in temperate climatic regions (Hollister, Craddock, et al., 1976) in middle Miocene sediments in the Bellingshausen Basin to the west of the Antarctic Peninsula (Schrader, 1976).

\section{Late Miocene: West Antarctic Ice-sheet Development}

By the middle late Miocene, only biosiliceous sediments were deposited on Maud Rise. These were dominated by diatom oozes but, at times, included silicoflagellate-rich oozes. In contrast with the Oligocene sediments described earlier, late Miocene and younger sediments reflect high siliceous productivity, simple water mass structure and more vigorous circulation essentially similar to those of the present day, which are controlled by the existence of the ACC and the Polar Front. The late Miocene also exhibits further increases in the abundance of ice-rafted detritus in sites adjacent to East Antarctica, indicating intensified iceberg activity (Grobe et al., this volume). Site 693 provides no evidence for the removal of the East Antarctic ice-sheet during the late Miocene. Brief episodes of climatic amelioration occurred at about 10.5 and $8.5 \mathrm{Ma}$, as indicated by a reappearance of calcareous biogenic material in the form of calcareous nannofossils and calcareous foraminifers at Sites 696 and 693 . These forms were particularly common at $\sim 10.5$ Ma near the beginning of the late Miocene. A distinct increase also occurred during these intervals in the relative abundances (up to $90 \%$ ) of a warmer diatom form, Denticulopsis dimorpha (Burckle et al., this volume). According to S. Wise (pers. comm.), the presence of calcareous nannofossils at these times indicates that surface water temperatures were at or above $5^{\circ}-6^{\circ} \mathrm{C}$. The preservation of these assemblages may have resulted from a productivity increase of calcareous plankton, which temporarily depressed the CCD (Barker, Kennett, et al., 1988a). An absence of calcareous nannofossils at other times during the late Neogene suggests that surface-water temperatures near Antarctica were lower than $5^{\circ}-6^{\circ} \mathrm{C}$.

The most important development during the late Miocene was the formation of the West Antarctic ice-sheet. This event is best recorded in Site 696. Beginning in the early part of the late Miocene, there was the appearance of hemipelagic sediments. At the same time, ice-rafted detritus began to be deposited and has continued at this location to the present day. Chlorite and illite became dominant clay minerals, reflecting an increase in physical weathering on West Antarctica (Robert and Maillot, this volume). However, smectite remained important, perhaps as a result of the erosion of older parent rocks.

Rapid deposition of turbidites occurred during the late Miocene in the Weddell Abyssal Plain (Site 694). Although poorly recovered, these seem to be dominated by sands that are in- 
ferred, from a number of criteria, to have been derived from the Antarctic Peninsula and the present-day region of the FilchnerRonne ice shelf rather than from East Antarctica (Barker, Kennett, et al., 1988a). Anderson et al. (1986) showed that turbidite sands from the central abyssal plain exhibit mineralogical maturity by being enriched in quartz and containing relatively few lithic grains compared with modern slope deposits. They believe that these sands were derived from well-sorted sedimentary sources more typical of temperate glacial conditions when the margins included glacial outwash streams and beaches. These characteristics suggest a West Antarctic source during the late Miocene rather than an East Antarctic source as suggested by Anderson et al. (1986). The sequence suggests considerable climatic/cryospheric instability in the sediment source area. Ice-rafted detritus, exhibiting a wide size range, was found discontinuously throughout the sequence in varying abundances, suggesting changes in the intensity of the Antarctic cryosphere during the middle and late Miocene.

In summary, data from Leg 113 drilling support the hypothesis that the West Antarctic ice-sheet developed during the late Miocene (Mercer, 1976; Ciesielski et al., 1982). Furthermore, the sequences indicate considerable instability of this ice-sheet until the end of the Miocene. Related oceanic variability might have led to the occurrence of a silicoflagellate assemblage indicative of environmental stress (McCartney and Wise, this volume).

\section{Early Pliocene: Further Ice-growth or Ice-sheet Instability?}

Further important changes in Antarctic climate occurred close to the Miocene/Pliocene boundary or perhaps during the earliest Pliocene. One of the most noticeable was an increase in siliceous biogenic sedimentation rate in many of the Weddell Sea sites, leading to an acme of preservation and abundance during the early Pliocene (Barker, Kennett, et al., 1988a). This reflects a distinct increase in diatom productivity throughout the region, probably as a result of an amelioration in climate that reduced sea-ice cover and led to a southward migration of the Polar Front. Higher rates of siliceous biogenic sedimentation during the Pliocene also occurred near the Polar Front to the north of the Weddell Sea (Ludwig, Krashenninikov, et al., 1983) and higher rates of calcareous biogenic productivity occurred at the same time in the South Pacific near the Subtropical Divergence (Kennett, von der Borch, et al., 1986). An important climatic shift near the Miocene/Pliocene boundary is implied by major changes in organic preservation in sediments and the isotopic composition of organic material (Macko and Pereira, this volume). This, in turn, suggests a major change in the process of carbon and nitrogen recycling through the Weddell Sea. There is considerable evidence from lower latitude areas for climatic warming during the early Pliocene (e.g., Kennett, 1986; Hodell and Kennett, 1986). However, the early Pliocene planktonic microfossil assemblages at Leg 113 sites did not seem to have undergone any major changes that would imply an Antarctic warming of sufficient magnitude to have caused a melting of a large proportion of the Antarctic ice-sheets at that time (e.g., Harwood, 1985).

The abundance of sand-sized, ice-rafted detritus markedly increased on Maud Rise at the beginning of the Pliocene (Fig. 9). Near the East Antarctic margin (Site 693), sediments became fine grained, although ice-rafted detritus remained common; also, smectite returned as an important clay mineral (Robert and Maillot, this volume; Grobe et al., this volume). Near the Antarctic Peninsula (Site 696), diatomaceous sediments were largely replaced by hemipelagic sediments as fine-grained terrigenous material increased markedly, causing higher sedimentation rates.

From approximately $4.8 \mathrm{Ma}$ (earliest Pliocene) to the present day, turbidite deposition virtually ceased at Site 694 (Weddell Abyssal Plain) and hemipelagic sediments were deposited (Barker,
Kennett, et al., 1988a). A thick sequence of turbidites, deposited immediately before this change, is considered to have an age close to the Miocene/Pliocene boundary based on diatom biostratigraphy (Barker, Kennett, et al., 1988a; Gersonde et al., this volume). The magnetostratigraphic interpretation indicates that the hemipelagic sedimentation began no later than $4.7 \mathrm{Ma}$ and probably $4.8 \mathrm{Ma}$, during the early reversed interval of the Gilbert Chron (Barker, Kennett, et al., 1988a). These turbidites were probably derived from the West Antarctic rather than from the East Antarctic continental margins. The cessation of turbidite deposition at Site 694 has been interpreted to represent the development of a stable West Antarctic ice-sheet and associated ice shelves in the earliest Pliocene (Barker, Kennett, et al., 1988a). This in turn starved the Weddell Abyssal Plain of its former major sediment supply.

A major question related to the stability of the West Antarctic ice-sheet during the late Neogene remains. Ciesielski and Weaver (1974) and Ciesielski et al. (1982) suggested that early Pliocene warming may have caused instability and partial deglaciation of the West Antarctic ice-sheet. However, if our interpretation of the depositional history of the Weddell Abyssal Plain is correct, the West Antarctic ice-sheet may have actually been a relatively stable feature on Antarctica during much of the Pliocene. Alternate scenarios involving ice-sheet instability during early Pliocene relative warmth are presented in this volume (Pudsey, this volume; Grobe et al., this volume), based on studies of sites on the continental margins.

Recent work on West Antarctic margin sedimentation (Larter and Barker, 1989) suggests that: (1) provision of sediment to the upper continental slope is highly systematic within a single glacial/interglacial cycle, which will tend toward cyclicity in the creation of turbidites and slumps by load-induced instability. Large amounts of unsorted glacial till are provided during glacial maxima, little or nothing during glacial minima; (2) once the typical inward-sloping Antarctic shelf profile has been created, by glacial erosion during a particularly intense glacial maxima, sediment is not transported beyond the continental shelf edge during lesser subsequent glaciations (even during maxima) if the grounded ice-sheet does not reach the shelf break. Sediment would be deposited within the shelf basin; (3) unsorted glacial sediment can maintain much steeper slopes without major instability than can well-sorted sediment.

It is possible, therefore, that the virtual absence of turbidites younger than 4.8-4.7 Ma at Site 694 may have resulted from mild amelioration of climate in the early Pliocene during which the glacially eroded sediments were trapped in the inward-sloping shelf basin. Renewed cryospheric development during the late Pliocene may have then loaded the upper continental slope with freshly eroded, unsorted glacial tills, the greater stability of which minimized the incidence and scale of slope failure and hence turbidities in the abyssal plain. If the dominant factor is the stability of unsorted sediments on the upper continental slope, than the inference of an early Pliocene climatic amelioration is unnecessary.

Additional studies are required, especially to better constrain the chronology of events during this time of rapid climate fluctuations.

\section{Late Pliocene: Sea-ice Expansion}

A further step in the development of the Antarctic cryosphere occurred during the middle to late Pliocene between about 3 and $2.4 \mathrm{Ma}$. At this time, the final major changes occurred in Antarctica, leading to environmental conditions like those of the present day. The first evidence for change is a regional decrease in sedimentation rates beginning at about $3 \mathrm{Ma}$ and largely resulting from a reduction in the supply of terrigenous sediments to the continental margins of the Weddell Sea. This may 
have resulted from the permanent grounding of the ice shelf to the edge of the continental shelf along much of the Antarctic margin (Grobe, 1986; Barker, Kennett, et al., 1988a). The exception is Site 697 in Jane Basin, where hemipelagic sedimentation rates remained high. Thus oscillations in the size of the West Antarctic ice-sheet were sufficiently large to maintain a supply of sediment to the nepheloid layer of the AABW western boundary current in the western Weddell Sea (Pudsey, this volume; Pudsey et al., 1988) but not to the Weddell Abyssal Plain. Near the Dronning Maud Land coast, siliceous biogenic sediments remained important in the sequence (Site 693) until about 3.3-3.0 $\mathrm{Ma}$, at which time they decreased markedly (Grobe et al., this volume). This almost certainly reflects an expansion of continuous sea-ice cover over this region, limiting light in surface waters and hence suppressing diatom productivity.

Further to the north, in the area of the South Orkney microcontinent (Site 697), inferred sea-ice expansion was slightly later, occurring about 2.5-2.4 Ma during the late Gauss Chron (Gersonde et al., in press; Burckle et al., this volume). From this time onward, diatom abundance and quality of preservation in the sediments were drastically reduced, and the biogenic opal abundance decreased dramatically. Furthermore, an associated general increase occurred in the relative abundance of the seaice related diatom Eucampia antarctica. These changes indicate that sea-ice covered the region for much of the year. The Filchner/Ronne and Ross Ice Shelves expanded further northward at this time (Anderson, 1972; Fillon, 1975).

This represents the last major cooling trend in the Antarctic (Hays and Opdyke, 1967; Shackleton and Kennett, 1975) and occurred at the same time as major ice growth in the Northern Hemisphere (Shackleton and Opdyke, 1977). Most workers believe that global ice growth in the late Pliocene $(\sim 2.4 \mathrm{Ma})$ was concentrated in the Northern Hemisphere (Burckle et al., this volume). This was at the time of the first extensive ice rafting in the open-ocean North Atlantic (Backman, 1979; Shackleton et al., 1984). The Weddell Sea sedimentology record, however, strongly indicates that major ice growth also occurred on Antarctica (Burckle et al., this volume).

\section{Quaternary Climatic Cycles}

The abundance of biogenic siliceous sediments remained relatively low during the Quaternary. One of the more conspicuous aspects of late Quaternary sedimentary patterns are the clear sedimentary cycles in almost all sites that have been interpreted as resulting from climatic cycles (Pudsey, this volume; Grobe et al., this volume). Glacial episodes during the late Quaternary (Site 697) are marked by sediments with relatively low siliceous biogenic components and lower average grain size compared with sediments from interglacial episodes. This implies increased seaice cover, reducing diatom productivity, and weaker bottom water flow during episodes. The converse is true for interglacial episodes.

The Quaternary also contains a thin (up to $2.5 \mathrm{~m}$ ) layer of foraminiferal ooze or a calcareous foraminiferal-rich zone. This unusual layer was found throughout the Weddell Sea in almost all of the Leg 113 sites shallower than $\sim 3000$ m (Barker, Kennett, et al., 1988a) and in piston cores from other Weddell Sea locations (Grobe et al., this volume). The layer consists primarily of a concentration of a single planktonic foraminiferal species Neogloboquadrina pachyderma associated with low-diversity calcareous benthic foraminiferal and coccolithophorid assemblages. There are no records of coccolithophorids living at these latitudes today, nor have they been recorded from the Pliocene. The exact age within the Quaternary of this layer still needs to be determined. Intervals warmer than the present day have been inferred from the early Holocene (e.g., Hays, 1965) and the early late Quaternary (e.g., Hays et al., 1976). It is not clear what conditions led to the accumulation of this layer, but the evidence suggests that at some time during the Quaternary, surface water conditions in the Weddell Sea were warmer than at any time during the previous 5 m.y. (Barker, Kennett, et al., 1988a). Higher productivity of the calcareous plankton temporarily depressed the CCD in some parts of the Weddell Sea area.

\section{ACKNOWLEDGMENTS}

This chapter is a summary of the contributions of many individuals' investigations on ODP Leg 113 cores. We thank them all, but especially the scientific party of Leg 113 for their stimulating and constructive collaborations. This manuscript has been significantly improved by the constructive suggestions of numerous colleagues. S. O'Connell, E. Thomas, C. Robert, S. W. Wise, Jr., and two anonymous reviewers read and commented on the entire manuscript; particular parts of the manuscript were read by L. D. Stott, L. H. Burckle, R. A. Askin, E. Barrera, and B. T. Huber. Also, useful improvements resulted from discussions with J. C. Zachos, T. J. Crowley, and D. Warnke. We thank them all for their contributions. The manuscript was typed by Donna Good Higbee; Diana Kennett provided editorial assistance. The research was partially supported by NSF grants DPP89-11554 (Division of Polar Programs) and OCE8817135 (Submarine Geology and Geophysics).

\section{REFERENCES}

Anderson, J. B., 1972. The marine geology of the Weddell Sea [Ph.D. dissert.]. Florida State Univ., Tallahassee.

Anderson, J. B., Wright, R., and Andrews, B. A., 1986. Weddell Fan and associated abyssal plain, Antarctica: morphology, sediment processes and factors influencing sediment supply. Geo-Mar. Lett., 6: 121-129.

Arthur, M. A., Zachos, J. C., and Jones, D. S., 1987. Primary productivity and the Cretaceous/Tertiary boundary event in the oceans. Cret. Res., 8:43-54.

Askin, R. A., 1988. Campanian to Paleocene palynological succession of Seymour and adjacent islands, northeastern Antarctic Peninsula. Geol. Soc. Am. Mem., 169:131-153.

1989. Endemism and heterochroneity in the Late Cretaceous (Campanian) to Paleocene palynofloras of Seymour Island, Antarctica: implications for origins, dispersal and palaeoclimates of southern floras. In Crame, J. A. (Ed.), Origins and evolution of the Antarctic Biota, Geol. Soc. Spec. Publ., 47:107-119.

Backman, J., 1979. Pliocene biostratigraphy of DSDP sites 111 and 116 from the North Atlantic Ocean and the age of Northern Hemisphere glaciation. Acta Univ. Stockh. Stockholm. Contrib. Geo., 32:115137.

Barker, P. F., and Burrell, J., 1977. The opening of the Drake Passage. Mar. Geol., 25:15-34.

1982. The influence upon Southern Ocean circulation sedimentation and climate of the opening of Drake Passage. In Craddock, C. (Ed.), Antarctic Geoscience, (Univ. of Wisconsin Press), 377-385.

Barker, P. F., Kennett, J. P., et al., 1988a. Proc. ODP, Init. Repts., 113: College Station, TX (Ocean Drilling Program).

Barker, P. F., Kennett, J. P., and Scientific Party, 1988b. Weddell Sea palaeoceanography: preliminary results of ODP Leg 113. Palaeogeogr., Palaeoclimatol., Palaeoecol., 67:75-102.

Barrera, E., Huber, B. T., Savin, S. M., and Webb, P.-N., 1987. Antarctic marine temperatures: Late Campanian through early Paleocene. Paleoceanography, 2:21-47.

Barrett, P. J., Elson, D. P., Harwood, D. M., McKelvey, B. C., and Webb, P.-N., 1987. Mid-Cenozoic record of glaciation and sea-level change on the margin of the Victoria Land basin, Antarctica. Geology, 15:634-637.

Beckmann, J.-P., 1960. Distribution of benthonic foraminifera at the Cretaceous-Tertiary boundary of Trinidad (West-Indies). Internat. Geol. Cong., Rept. 21st Session, Norden Part V: The CretaceousTertiary Boundary, 57-69.

Benson, R. H., 1975. The origin of the psychrosphere as recorded in changes of deep-sea ostracode assemblages. Lethaia, 8:69-83. 
Benson, R. H., Chapman, R. E., and Deck, L. T., 1984. Paleoceanographic events and deep-sea ostracodes. Science, 224:1334-1336.

Berger, W. H., Vincent, E., and Thierstein, H. R., 1981. The deep-sea record: major steps in Cenozoic ocean evolution. Soc. Econ. Paleontol. Mineral. Spec. Publ., 32:489-504.

Berggren, W. A., Kent, D. V., and Flynn, J. J., 1985a. Paleogene geochronology and chronostratigraphy. In Snelling, N. J. (Ed.), The Chronology of the Geological Record. Mem. 10, Geol. Soc., London, 141-195.

Berggren, W. A., Kent, D. V., Flynn, J. J., and Van Couvering, J. A., 1985b. Cenozoic geochronology. Geol. Soc. Am. Bull., 96:1407-1418.

Berggren, W. A., Kent, D. V., and Van Couvering, J. A., 1985c. The Neogene: Part 2, Neogene geochronology and chronostratigraphy. In Snelling, N. J. (Ed.), Geochronology of the Geological Record, Geol. Soc. London, Mem. 10:211-260.

Betzer, P. R., Carder, K. L., Duce, R. A., Merrill, J. T., Tindale, N. W., Uematsu, M., Costello, D. K., Young, R. W., Feely, R. A., Breland, J. A., Bernstein, R. E., and Greco, A. M., 1988. Long range transport of giant mineral aerosol particles. Nature, 336:568-571.

Birkenmajer, K., 1987. Oligocene-Miocene glacio-marine sequences of King George Island (South Shetland Islands), Antarctica. Palaeontol. Polonica, 49:9-36.

Birkenmajer, K., and Zastawniak, E., 1989. Late Cretaceous-Tertiary floras of King George Island, West Antarctica: their stratigraphic distribution and palaeoclimatic significance. In Crame, J. A. (Ed.), Origins and evolution of the Antarctic biota. Geol. Soc. Spec. Publ., 47.

Braga, G., de Biase, R., Grunig, A., and Proto Decima, F., 1975. Foraminiferi bentonici del Paleocene ed Eocene della Sezione di Passagno. Schweiz. Palaontol. Abh., 97:85-111.

Brass, G. W., Southam, J. R., and Peterson, W. H., 1982. Warm saline bottom water in the ancient ocean. Nature, 296:620-623.

Brewster, N. A., 1980. Cenozoic biogenic silica sedimentation in the Antarctic Ocean, Based on Two Deep Sea Drilling Project Sites. Geol. Soc. Am. Bull., 91:337-347.

Broecker, W. S., and Peng, T. H., 1982. Tracers in the Sea: Palisades, NY (Eldigio Press).

Case, J. A., 1988. Paleogene floras from Seymour Island, Antarctic Peninsula. Geol. Soc. Am. Mem. 169.

Chamberlin, T. C., 1906. On a possible reversal of deep-sea circulation and its influence on geologic climates. J. Geol., 14:363-373.

Ciesielski, P. F., and Weaver, F. M., 1974. Early Pliocene temperature changes in the Antarctic Seas. Geology, 12:511-515.

Ciesielski, P. F., Ledbetter, M. T., and Ellwood, B. B., 1982. The development of Antarctic glaciation and the Neogene paleo-environment of the Maurice Ewing Bank. Mar. Geol., 46:1-51.

Cranwell, L. M., Harrington, H. J., and Speden, L. G., 1960. Lower Tertiary microfossils from McMurdo Sound, Antarctica. Nature, 86: 700-702.

Deacon, G.E.R., 1937. The hydrology of the Southern Ocean. Discovery Repts., 15:1-124.

1963. The Southern Ocean. In Hill, M. N. (Ed.), The Sea, 2: New York (Interscience), 281-296.

1979. The Weddell Gyre. Deep-Sea Res., 26A:981-995.

Dercourt, J., Zonenshain, L. P., Ricou, L.-E., Kazmin, V. G., Le Pichon, X., Knipper, A. L., Grandjaquet, C., Sbortshikov, I. M., Geyssant, J., Lepvrier, C., Pechersky, D. H., Boulin, J., Sibuet, J.C., Savostin, L. A., Sorokhtin, O., Westphal, M., Bazhenov, M. L., Lauer, J. P., and Biju-Duval, B., 1986. Geological evolution of the Tethys belt from the Atlantic to the Pamirs since the Lias. In Aubouin, J., Le Pichon, X., and Monin, A. S. (Eds.), Evolution of the Tethys. Tectonophysics, 123:241-315.

Drewry, D. J., 1986. Glacial Geologic Processes: London (Edward Arnold).

Echols, R. J., 1971. Distribution of foraminifera in sediments of the Scotia Sea area, Antarctic waters. Antarct. Res. Ser., Am. Geophys. Union, 15:93-168.

Echols, R. J., and Kennett, J. P., 1973. Distribution of Foraminifera in the surface sediments. In Goodell, H. G. (Ed.), Marine sediments of the Southern Oceans. Antarctic Map Folio Ser., 17:13-17, Am. Geogr. Soc., New York.
Fillon, R. H., 1975. Late Cenozoic paleo-oceanography of the Ross Sea, Antarctica. Geol. Soc. Am. Bull., 86:839-845.

Foldvik, A., and Gammelsrod, T., 1988. Notes on Southern Ocean hydrography, sea-ice and bottom water formation. Palaeogeogr., $\mathrm{Pa}$ laeoclimatol., Palaeocol., 67:3-17.

Foster, T. D., and Carmack, E. C., 1976. Temperature and salinity structure in the Weddell Sea. J. Phys. Oceanogr., 6:36-44.

Foster, T. D., and Middleton, J. H., 1979. Variability in the bottom water of the Weddell Sea. Deep-Sea Res., 26:743-762.

1980. Bottom water formation in the eastern Weddell Sea. Deep-Sea Res., 27A:367-381.

Frakes, L. A., 1979. Climates Throughout Geologic Time: Amsterdam (Elsevier Scientific Publ. Co.).

Georgi, D. T., 1981. Circulation of bottom waters in the southwestern South Atlantic. Deep-sea Res., 28A:959-979.

Gersonde, R., Abelmann, A., and Spieß, (in press). Plio-Pleistocene Paleoceanography in the Weddell Sea-siliceous microfossil evidence. In Bleil, V., and Thiede, J. (Eds.), Geological History of Polar Oceans Arctic versus Antarctic. NATO/ASI Series C: Dortrecht (Kluwer Academic Publishers).

Gill, A. E., 1973. Circulation and bottom water production in the Weddell Sea. Deep-sea Res., 20:111-140.

Goodell, H. G., 1973. Marine sediments of the Southern Oceans. Antarctic Map Folio Ser., 17, Am. Geogr. Soc., New York.

Gordon, A. L., 1971. Comment on the Weddell Sea produced Antarctic Bottom Water. J. Geophys. Res., 76:5913-5914.

Gordon, L., Martinson, D. G., and Taylor, H. W., 1981. The winddriven circulation in the Weddell-Enderby basin. Deep-Sea Res., 28A: 151-163.

Grikurov, G. E., 1982. Structure of Antarctica and outline of its evolution. In Craddock, C. (Ed.), Antarctic Geoscience, I.U.G.S. Series B, 4:791-804.

Grobe, H., 1986. Sedimentation processes on the Antarctic continental margin at Kapp Norvegia, during the late Pleistocene. Geol. Rundsch., 75:97-104.

Haq, B. U., Hardenbol, J., and Vail, P. R., 1987. The new chronostratigraphic basis of Cenozoic and Mesozoic sea level cycles. Cushman Found., Foram. Res. Spec. Pub., 24:7-13.

Haq, B. U., Lohmann, G. P., and Wise, S. W., Jr., 1977. Calcareous nannoplankton biogeography and its paleoclimatic implications: $\mathrm{Ce}$ nozoic of the Falkland Plateau (DSDP Leg 36) and Miocene of the Atlantic Ocean. In Barker, P. F., Dalziel, I.W.D., et al., Init. Repts. DSDP 36: Washington (U.S. Govt. Printing Office), 745-759.

Harwood, D. M., 1985. Late Neogene climatic fluctuations in the southern high-latitudes: implications of a warm Pliocene and deglaciated Antarctic continent. So. African J. Sci., 81:239-241. 1986. Diatoms. In Barrett, P. J. (Ed.), Antarctic history. N.Z. Dept. Sci. Indust. Res. Bull., 237:69-114.

1988. Upper Cretaceous and lower Paleocene diatom and silicoflagellate biostratigraphy of Seymour Island, eastern Antarctic Peninsula. Geol. Soc. Am. Mem., 169:55-129.

Hayes, D. E., Frakes, L. A., et al., 1975. Init. Repts. DSDP, 28: Washington (U.S. Govt. Printing Office).

Hays, J. D., 1965. Radiolaria and Late Tertiary and Quaternary History of the Antarctic Seas. Biol. Antarctic Seas. Antarctic Res. Series 5, 2:125-184

Hays, J. D., Imbrie, J., and Shackleton, N. J., 1976. Variations in the Earth's Orbit: Pacemaker of the Ice Ages. Science, 194:1121-1132.

Hays, J. D., and Opdyke, N. D., 1967. Antarctic radiolaria, magnetic reversals and climatic change. Science, 158:1001-1011.

Hodell, D., and Kennett, J. P., 1986. Late Miocene-Early Pliocene stratigraphy and paleoceanography of the South Atlantic and Southwest Pacific Oceans: A Synthesis. Paleoceanography, 1:285-311.

Hollister, C. D., Craddock, C., et al., 1976. Init. Repts. DSDP, 35: Washington (U.S. Govt. Printing Office).

Hsü, K. J., and McKenzie, J. A., 1985. A "Strangelove" Ocean in the earliest Paleogene. In Sundquist, E., and Broecker, W. S. (Eds.), The Carbon Cycle and Atmospheric $\mathrm{CO}_{2}:$ Natural Variations, Archean to Present: Washington (Am. Geophys. Union), 487-492.

Jenkins, D. G., 1975. Cenozoic planktonic foraminiferal biostratigraphy of the Southwestern Pacific and Tasman Sea, DSDP Leg 29, In 
Kennett, J. P., and Houtz, R. E., et al., Init. Repts. DSDP, 29: Washington (U.S. Govt. Printing Office), 449-467.

Katz, M. E., and Miller, K. G., 1988. Paleocene to Eocene benthic foraminiferal turnover, Atlantic sector Southern Ocean. Am. Abstr. Programs, 20:A251.

Keigwin, L. D., and Keller, G., 1984. Middle Oligocene climatic change from equatorial Pacific DSDP Site 77. Geology, 12:16-19.

Keller, G., 1989. Extended Cretaceous-Tertiary boundary extinctions and delayed population change in planktonic foraminifera from Brazos River, Texas. Paleoceanography, 4(3):287-332.

Keller, G., Herbert, T., Dorsey, R., D'Hondt, S., Johnsson, M., and Chi, W. R., 1987. Global distribution of late Paleogene hiatuses. Geology, 16:199-203.

Kemp, E. M., 1975. Palynology of Leg 28 drill sites, Deep Sea Drilling Project. In Hayes, D. E., Frakes, L. A., et al., Init. Repts. DSDP, 28: Washington (U.S. Govt. Printing Office), 599-623.

Kemp, E. M., and Barrett, P. J., 1975. Antarctic glaciation and early Tertiary vegetation. Nature, 258:507-508.

Kennett, J. P., 1966. Foraminiferal evidence for a shallow calcium carbonate solution boundary Ross Sea, Antarctica. Science, 153:191193.

1977. Cenozoic evolution of Antarctic glaciation, the circumAntarctic Ocean, and their impact on global paleoceanography. $J$. Geophys. Res., 82:3843-3860.

1978. The development of planktonic biogeography in the Southern Ocean during the Cenozoic. Mar. Micropaleontol., 3:301345 .

1986. Miocene to early Pliocene oxygen and carbon isotope stratigraphy of the Southwest Pacific, DSDP Leg 90, In Kennett, J. P., von der Borch, C. C., et al., 90: Washington (U.S. Govt. Printing Office), 1383-1411.

Kennett, J. P., and Shackleton, N. J., 1976. Oxygen isotope evidence for the development of the psychrosphere $38 \mathrm{Myr}$. ago. Nature 260:513515 .

Kennett, J. P., Houtz, R. E., et al., 1975. Init. Repts. DSDP, 29: Washington (U.S. Govt. Printing Office).

Kennett, J. P., von der Borch, C. C., et al., 1986. Init. Repts. DSDP, 90: Washington (U.S. Govt. Printing Office).

Lagoe, M. B., 1983. Oligocene through Pliocene Foraminifera from the Yakataga Reef Station, Gulf of Alaska Tertiary Province, Alaska. Micropaleontology, 29:202-222.

Larter, R. D., and Barker, P. F., 1989. Seismic stratigraphy of the Antarctic Peninsula Pacific margin: a record of Pliocene-Pleistocene ice volume and paleoclimate. Geology, 17:731-734.

Loutit, T. S., Kennett, J. P., and Pisias, N. G., 1983. Pacific Miocene carbon isotope stratigraphy using benthonic foraminifera. Earth Planet. Sci. Lett., 66:48-62.

Ludwig, W. J., Krasheninnikov, V. A., et al., 1983. Init. Repts. DSDP, 71: Washington (U.S. Govt. Printing Office).

Mantyla, W., and Reid, J. L., 1983. Abyssal characteristics of the World Ocean waters. Deep-Sea Res., 30:805-833.

Martini, E., 1971. Standard Tertiary and Quaternary calcareous nannoplankton zonation. In Farinacci, A. (Ed.), Roma: Rome (Edizioni Technoscienza), 2:739-785.

Matthews, R., and Poore, R. Z., 1980. Tertiary ${ }^{18} \mathrm{O}$ record and glacioeustatic sea-level fluctuations. Geology, 8:501-504.

Mercer, J. H., 1976. Glacial history of southernmost South America. Quat. Res., 6:125-166.

Mildenhall, D. C., 1987. CIROS-1 drillhole, McMurdo Sound, Antarctica: terrestrial palynology (Abstract). N. Z. Antarctic Record, 7:58.

Miller, K. G., and Fairbanks, R. G., 1983. Evidence for Oligocene-Middle Miocene abyssal circulation changes in the western North Atlantic. Nature, 306:250-253.

1985. Oligocene to Miocene carbon isotope cycles and abyssal circulation changes. In Sundquist, E. T., and Broecker, W. S. (Eds.), The Carbon Cycle and Atmospheric Natural Variations Archean to Present. Am. Geophys. Union, Mono. Ser., 32:469-486.

Miller, K. G., and Thomas, E., 1985. Late Eocene to Oligocene benthic foraminiferal isotopic record, Site 574, equatorial Pacific. In Mayer, L., Theyer, F., et al., Init. Repts. DSDP, 85: Washington (U.S. Govt. Printing Office), 771-777.

Miller, K. G., Fairbanks, R. G., and Mountain, G. S., 1987a. Tertiary oxygen isotope synthesis, sea level history, and continental margin erosion. Paleoceanography, 2:1-19.
Miller, K. G., Janecek, T. R., Katz, M. E., and Keil, D. J., 1987b. Abyssal circulation and benthic foraminiferal changes near the Paleocene/ Eocene boundary. Paleoceanography, 2:741-761.

Millot, G., 1970. Geology of clays: New York (Springer-Verlag).

Murphy, M. G., and Kennett, J. P., 1986. Development of latitudinal thermal gradients during the Oligocene: oxygen-isotope evidence from the southwest Pacific. In Kennett, J. P., von der Borch, C. C., et al., Init. Repts. DSDP, 90: Washington (U.S. Govt. Printing Office), $1347-1360$

Oberhänsli, H., and Tourmarkine, M., 1985. The Paleogene oxygen and carbon isotope history of Sites 522,523 , and 524 from the central South Atlantic. In Hsü, H. J., and Weissert, A. (Eds.), South Atlantic Paleoceanography, Cambridge (Cambridge Univ. Press), 124-147.

Oberhänsli, H., McKenzie, J., Tourmarkine, M., and Weissert, H., 1984. A paleoclimatic and paleoceanographic record of the Paleogene in the Central South Atlantic (Leg 73, Sites 522, 523 and 524). In Hsü, K. J., La Brecque, J. L., et al., Init. Repts. DSDP, 73: Washington (U.S. Govt. Printing Office), 737-747.

Oglesby, R. J., 1989. A GCM study of Antarctic glaciation. Climate Dynamics, 3:135-156.

Okada, H., and Bukry, D., 1980. Supplementary modification and introduction of code numbers to the low-latitude coccolith biostratigraphic zonation. Mar. Micropaleontol., 5:321-325.

Owen, R. M., and Rea, D. K., 1985. Sea-floor hydrothermal activity links climate to tectonics: the Eocene carbon dioxide greenhouse. Science, 227:166-169.

Pitman, W. C., II, 1978. Relationship between eustasy and stratigraphic sequences of passive margins. Geol. Soc. Am. Bull., 89:1389-1403.

Pudsey, C. J., Barker, P. F., and Hamilton, N., 1988. Weddell Sea abyssal sediments: a record of Antarctic Bottom Water flow. Mar. Geol., $81: 289-314$.

Robert, C., and Chamley, H., (in press). Paleoenvironmental significance of clay mineral associations at the Cretaceous-Tertiary transition.

Robin, G. de Q., 1988. The Antarctic ice sheet, its history and response to sea level and climate changes over the past 100 million years. $\mathrm{Pa}$ laeogeog., Palaeoclimatol., Palaeoecol., 67:31-50.

Rögl, F., and Hochuli, P., 1976. The occurrence of Bolboforma a probable algal cyst, in the Antarctic Miocene of DSDP Leg 35. In Hollister, C. D., Craddock, C., et al., Init. Repts. DSDP, 35: Washington (U.S. Govt. Printing Office), 713-719.

Savin, S. M., Douglas, R. G., and Stehli, F. G., 1975. Tertiary marine paleotemperatures. Geol. Soc. Am. Bull., 86:1499.

Schlich, R., Wise, S. W., Jr., et al., 1989. Proc. ODP, Init. Repts., 120: College Station, TX (Ocean Drilling Program).

Schnitker, D. 1979. Cenozoic deep-water benthic foraminifers, Bay to Biscay. In Montadert, L., Roberts, D. G., et al. (Eds.), DSDP Init. Repts., 48: Washington (U.S. Govt. Printing Office), 377-414.

Schrader, H. J., 1976. Cenozoic planktonic diatom biostratigraphy of the Southern Pacific ocean. In Hollister, C. D., Craddock, C., et al., Site 325: Init. Repts. DSDP, 35: Washington (U.S. Govt. Printing Office), 605-671.

Seabrooke, J. M., Hufford, G. L., and Elder, R. B., 1971. Formation of Antarctic Bottom Water in the Weddell Sea. J. Geophys. Res., 76: 2164-2178.

Shackleton, N. J., 1987. The carbon isotope record of the Cenozoic: History of organic carbon burial and of oxygen in the ocean and atmosphere. In Brooks, J., and Fleet, A. J. (Eds.), Marine Petroleum Source Rocks. Spec. Publ. Geol. Soc. (London), 26:423-434.

Shackleton, N. J., and Kennett, J. P., 1975. Paleotemperature history of the Cenozoic and the initiation of Antarctic glaciation: Oxygen and carbon isotope analyses in DSDP sites 277,279 and 281 . In Kennett, J. P., Houtz, R. E., et al., Init. Repts. DSDP, 29: Washington (U.S. Govt. Printing Office), 143-756.

Shackleton, N. J., and Opdyke, N. D., 1977. Oxygen isotope and paleomagnetic evidence for early Northern Hemisphere glaciation. $\mathrm{Na}$ ture, 270:216-219.

Shackleton, N. J., Hall, M. A., and Boersma, A., 1984. Oxygen and carbon isotope data from Leg 74 foraminifers. In Moore, T. C., Jr., Rabinowitz, P. D., et al., Proc. ODP, Sci. Results, 74: Washington (U.S. Govt. Printing Office), 599-612.

Shackleton, N. J., Corfield, R. M., and Hall, M. A., 1985. Stable isotope data and the ontogeny of Paleocene planktonic foraminifera. $J$. Foram. Res., 15:321-336. 
Shipboard Scientific Party, Leg 119, 1988. Early glaciation of Antarctica. Nature, 333:303-304.

Stott, L. D., and Kennett, J. P., in press. New constraints on early Tertiary palaeoproductivity from carbon isotopes in foraminifera. $\mathrm{Na}$ ture.

in prep. The Paleocene/Eocene boundary event: Greenhouse induced warming, oceanographic perturbation and extinction.

Stuchlik, L., 1981. Tertiary pollen spectra from Ezcurra Inlet Group of Admiralty Bay, King George Island (South Shetland Islands, Antarctica). Studia Geol. Polonica, 72:109-132.

Tjalsma, R. C., and Lohmann, G. P., 1983. Paleocene-Eocene bathyal and abyssal benthic foraminifera from the Atlantic Ocean. Micropaleontol. Spec. Publ., 4:1-90.

Treshnikov, A. F., Alekseyev, G. V., Sarukhanyan, E. J., and Smirnov, N. P., 1980. Water circulation in the Southern Ocean. Polar Geogr. and Geology, 4:21-35.

Truswell, E. M., 1983. Recycled Cretaceous and Tertiary pollen and spores in Antarctic marine sediments: a catalogue. Palaeontographica B., 186:121-174.

Vail, P. R., and Hardenbol, J., 1979. Sea level changes during the Tertiary. Oceanus, 22:71-79.

Vail, P. R., Mitchum, R. M., Jr., Todd, R. G., Widmier, J. M., Thompson, S., III, Sangree, J. B., Bubb, J. N., and Hatelid, W. G., 1977. Seismic stratigraphy and global changes of sea level. In Payton, C. E. (Ed.), Seismic stratigraphy-applications to hydrocarbon exploration. Assoc. Pet. Geol. Mem. 26:49-205.

Webb, P. N., Harwood, D. M., McKelvey, D. C., Mercer, J. H., and Stott, L. D., 1984. Cenozoic marine sedimentation and ice volume variation on the east Antarctic craton. Geology, 12:287-291.

Weiss, R. F., Ostlund, H. G., and Craig, H., 1979. Geochemical studies of the Weddell Sea. Deep-Sea Res., 26A:1093-1112.

Wise, S. W., Jr., 1983. Mesozoic and Cenozoic calcareous nannofossils recovered by Deep Sea Drilling Project Leg 71 in the Falkland Plateau region southwest Atlantic Ocean. In Ludwig, W. J., Krashenin- nikov, V. A., et al., Init. Repts. DSDP, 71: Washington (U.S. Govt. Printing Office), 481-550.

Wise, S. W., Jr., Gombos, A. M., and Muza, J. P., 1985. Cenozoic evolution of polar water masses, southwest Atlantic Ocean. In Hsü, K. J., and Weissert, H. J. (Eds.), South Atlantic Paleoceanography. Cambridge (Cambridge Univ. Press), 283-324.

Wolfe, J. A., 1978. A paleobotanical interpretation of Tertiary climates in the Northern Hemisphere. Am. Sci., 66:694-703.

1980. Tertiary climates and floristic relationships at high latitudes in the Northern Hemisphere. Palaeocology, 30:313-323.

Woodburne, M. O., and Zinsmeister, W. J., 1984. The first land mammal from Antarctica and its biogeographic implications. J. Paleontol., 58:913-948.

Woodruff, F., and Savin, S. M., 1989. Miocene deepwater oceanography. Paleoceanography, 4:87-140.

Zachos, J. C., and Arthur, M. A., 1986. Paleoceanography of the Cretaceous/Paleogene boundary event: inferences from stable isotopic and other data. Paleoceanography, 1:5-26.

Zachos, J. C., Arthur, M. A., and Dean, W. E., 1989. Geochemical evidence for suppression of pelagic marine productivity at the Cretaceous/Paleogene boundary. Nature, 337:61-64.

Zastawniak, E., Wrona, R., Gazdzicki, A., and Birkenmajer, K., 1985. Plant remains from the top part of the Point Hennequin Group (upper Oligocene), King George Island (South Shetland Islands, Antarctica). Studia Geol. Polonica, 81:143-164.

Zinsmeister, W. J., 1982. Late Cretaceous-early Tertiary molluscan biogeography of the southern circum-Pacific. J. Paleontol., 56:84-102.

Zinsmeister, W. J., Feldmann, R. M., Woodburne, M. O., and Elliott, D. H. (in press). Latest Cretaceous/earliest Tertiary transition on Seymour Island, Antarctica. Paleontology.

Date of initial receipt: 3 November 1989

Date of acceptance: 15 November 1989

Ms 113B-195 